\title{
VARIETIES OF STREPTOCOCCI WITH SPECIAL REFERENCE TO CONSTANCY
}

\author{
BENJAMIN JUNIOR CLAWSON \\ From the Department of Hygiene and Bacteriology, University of Chicago
}

The work reported in the following pages deals with the characteristics of strains of streptococci isolated from various sources. Particular attention is given to the constancy of the special characteristics of streptococci such as peculiarities in morphology, the action on the blood-agar plate, the fermentation of the various carbohydrates, and the immune reactions such as agglutination and complement fixation. An attempt has been made to discover whether the various classes adopted by different workers have sufficient relationship to source, habits, pathogenesis, or any other particular characteristic to justify such grouping. A review of the literature is not given, since the literature on the work which has been done on streptococci has been well summarized by such recent workers as Holman, ${ }^{1}$ Blake, ${ }^{2}$ Aschner, ${ }^{3}$ and Brown. ${ }^{4}$

\section{Methods}

Mediums Used.-Meat infusion agar with a reaction of from $0.3-0.5 \%$ acid was used in all the work; $1.5 \%$ of agar was used. This gave a soft agar in which a considerable quantity of water of condensation was always present. Sodium chlorid, $0.85 \%$, was added to all mediums. The broth for sugar mediums was made sugar free by incubating the filtered meat infusion inoculated with B. coli for about twelve hours. The broth was adjusted to from $0.1-0.5 \%$ acid to phenolphthalein, $\mathrm{P}_{\mathrm{H}}$ 7.9-7.4. All of the broth contained $1 \%$ of Armour's peptone. The sugar broths were prepared by adding $1 \%$ of the sugar to the sugar-free broth, and enough litmus was added to give the broth a faint blue color. The broth was then sterilized in the autoclave at 10 lbs. of pressure for ten minutes. The inulin was placed in a mixture of 1 part serum and 3 parts water. Blood agar was prepared by adding $10 \%$ of defibrinated sheep blood to salt meat infusion agar. Ascitic fluid agar was prepared by adding $10 \%$ of ascitic fluid to the agar. Certified milk was used.

Method of Isolation and Cultivation.-Material was plated on blood agar or glucose litmus agar, and the plates were incubated at $37 \mathrm{C}$. for from 15-24 hours. The dilution method was used in all cases. Well isolated colonies were picked and transferred to blood agar slants or glucose broth. In all cases

Received for publication Oct. 4, 1919.

1 Jour. Med. Research, 1916, 34, p. 377.

2 Ibid., 1917, 36, p. 99.

- Jour. Infect. Dis., 1917, 21, p. 409.

4 Monograph of Rockefeller Institute for Medical Research, No. 9, January, 1919. 
these blood agar or glucose broth cultures were replated on blood agar and repicked to the blood agar slants. Pneumococci and streptococci were differentiated on the basis of morphology, the inulin fermentation, and the bile solubility test. All sugar mediums were inoculated from a 15-24 hour glucose-broth culture with one standard loopful of the culture. The glucosebroth culture from which the sugars were inoculated was tested by smear preparation for growth and purity of culture. The cultures in sugar mediums were grown at $37 \mathrm{C}$. for 5 days and then examined for acidity. All tubes which did not show an evident change in color were reported negative. These negative cultures were checked by using Andrade's indicator. All cultures were kept in storage on blood-agar slants at icebox temperature and transferred each month. Fifteen strains were kept at $37 \mathrm{C}$. for 10 months on blood-agar slants and ascitic-fluid-agar slants and transferred every week.

Agglutination.-Suspensions for agglutination were prepared by growing the organisms in salt broth for about twenty-four hours. A homogeneous suspension was obtained by shaking the salt-broth tube. Immune serum was prepared by injecting from 2-10 c c of a 24 -hour broth culture intravenously into a rabbit. These injections were continued for from 5-7 injections at intervals of from 5-8 days. The blood was taken from the heart, centrifugalized, and preserved in $0.5 \%$ phenol. Twelve rabbits were immunized respectively to 12 different hemolytic strains, and 5 rabbits were immunized to 5 different nonhemolytic strains. Controls were made with normal rabbit serum and with salt solution. The serum was also controlled with sterile salt broth to see that precipitation was not produced.

Complement Fixation.-The same serum was used as in the work with agglutination. The antigen was prepared according to Kinsella and Swift's method. The organisms to be used in the antigens were grown in large tubes of glucose-broth for 24 hours. The broth was centrifugalized and the sediment was washed twice with salt solution. The sediment was then dried and $10 \mathrm{mg}$. were dissolved in $5 \mathrm{cc}$ of a $2 \%$ antiformin solution in a water bath at $56 \mathrm{C}$. This solution was then neutralized to phenolphthalein with $\mathrm{N} / 20 \mathrm{H}_{2} \mathrm{SO}_{4}$ and made up to $10 \mathrm{cc}$. The chlorin was removed by adding a few drops of a $5 \%$ solution of sodium thiosulphate. The antigens were preserved with $0.5 \%$ phenol. In the complement fixation test $0.1 \mathrm{cc}$ of antigen was used with 3 different amounts of serum $(0.1 \mathrm{cc}, 0.05 \mathrm{cc}$, and $0.025 \mathrm{cc}$ ) and 2 units of complement. After incubation for one hour at $37 \mathrm{C} ., 2$ units of hemolytic amboceptor and $0.5 \mathrm{cc}$ of washed sheep red blood cells were added, and the tubes were incubated for another hour. The usual controls were made.

\section{SoUrCes of Material}

The sources from which the organisms used in this series were isolated may be grouped as follows: necropsies, respiratory passages and accessory openings, feces and urine, local suppurative processes, milk and milk products.

\section{Classification}

Morphology.-The early workers differentiated the strains of streptococci on the basis of morphology. It was thought at first that pathogenic strains of streptococci produced long chains and saprophytic strains short chains. Lingelsheim ${ }^{8}$ in 1899 first differentiated the pathogenic streptococci from those

- Jour. Exper. Med., 1918, 28, p. 181.

- Beitr. z. exper. Therap., 1899, 1, - 
TABLE 1

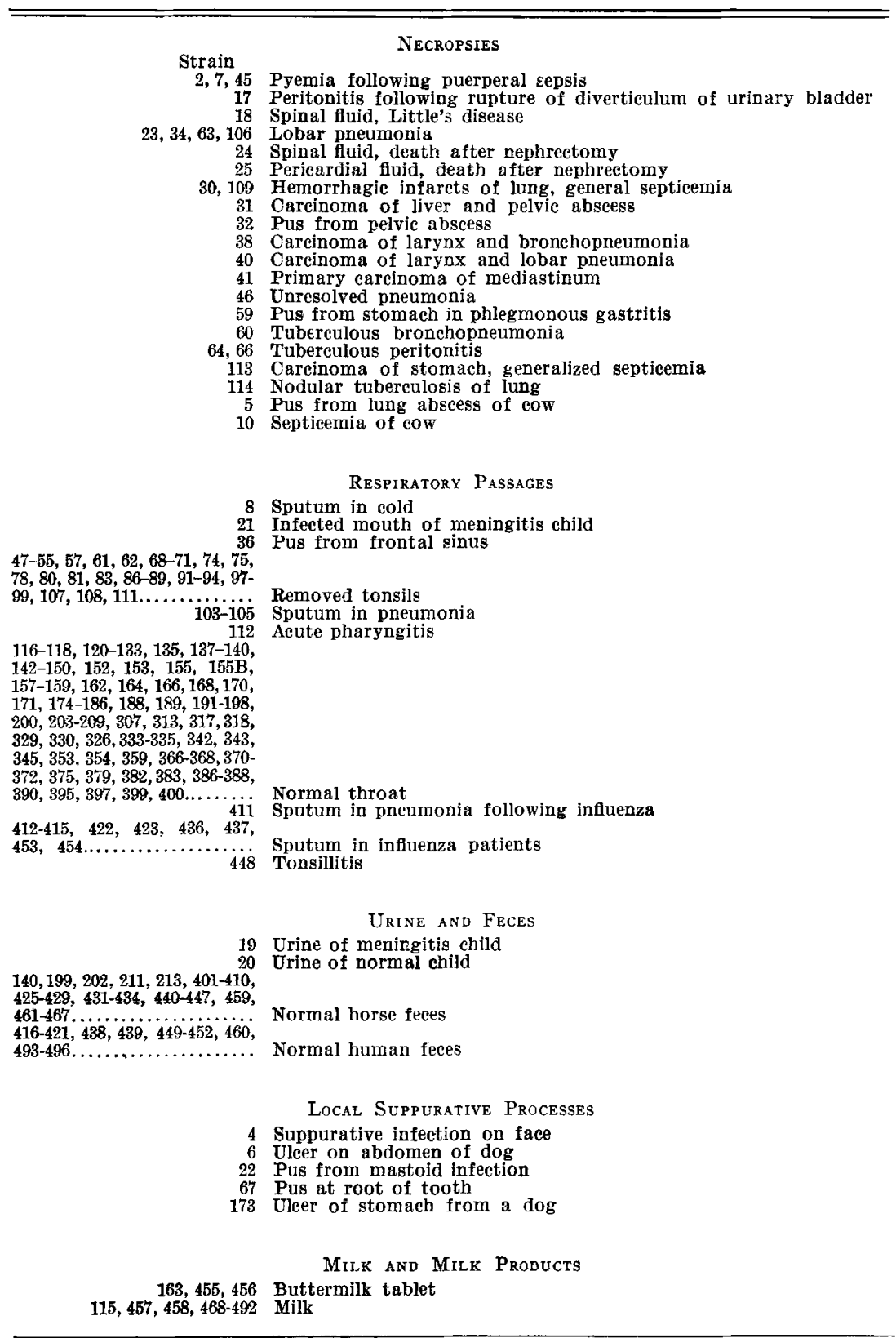


less pathogenic by means of the length of the chains produced. Those strains which formed chains of 8 or more cells he classified as Streptococcus longus, and those strains forming less than 8 cells in a chain he classified as Streptococcus brevis. The former was considered to be more pathogenic and more common in suppurative processes, while the latter was characteristic of the more saprophytic forms. I have found considerable variation in the length of chains depending on the medium whether solid or liquid and on the amount of water of condensation on the solid medium, but $I$ have not found any direct relation between the length of chains and pathogenesis. Many strains which were isolated from the blood of septicemia patients at first produced short chains on blood agar slants, but after growing for several months developed longer chains. When strains having long chains were grown on sterile tissue in salt solution there was a tendency to produce shorter chains. In general, streptococci isolated from the throat were found to be more segmented into pairs in the chain than the strains isolated from the blood of patients dying with septicemia. The shape of the cells seems to have some significance. Those strains isolated from the blood in general septicemia have cells which retain the spherical shape while those isolated from saprophytic conditions show elongation in the long axis of the chain. Several strains of pleomorphic streptococci were isolated from various sources, strain 17 from a case of peritonitis, strain 34 from the blood of a case of lobar pneumonia, strains 54 and 55 from removed tonsils, and strain 155 from the normal throat. All of these strains have changed to the segmented slightly elongated cells which form in chains.

The morphology of those strains grown at $37 \mathrm{C}$. for 10 months corresponds in general with the morphology of the same strains kept at icebox temperature and transferred once a month.

The question of the production of capsules in the streptococcus pneumococcus group has stimulated considerable discussion. Hiss, ${ }^{7}$ working with the various types of capsules produced by the pneumococci and the streptococci, decided that the capsule formation was not sufficient to separate the streptococci from the pneumococci. Holman ${ }^{1}$ in his scheme of classification represents the streptococci as noncapsule producers. In my series it has been found that the capsule-producing property varies somewhat. Of the 134 strains of hemolyzers, 20 produced capsules at one or more times. The intervals between the tests ranged from 1-11 months in duration. The strains which produce capsules seem to vary from time to time. Of the 20 strains of hemolyzers which produced capsules 15 varied from time to time. Sixty hours incubation proved to be the best time for determining capsular formation in milk. Most of the capsule producers among the hemolyzers were strains associated with acute pathologic processes such as pyemia, septicemia, and removed tonsils.

Capsule production among the nonhemolytic strains is more common than among the hemolyzers. Of the 150 strains of nonhemolyzers, 47 produced capsules at one or more determinations. Of these 47 strains, 27 showed the presence of capsules at every determination. Ten of these capsule producers were isolated from the pulp of removed tonsils, 5 from blood at necropsies, 2 from spinal fluid, one from a suppurative infection on the face, 24 from the normal throat, one from urine, one from a buttermilk tablet, 2 from milk, and one from the sputum of an influenza patient. As among the hemolytic

T Jour. Exper. Med., 1905, 6, p. 317. 
capsule producers the nonhemolytic-capsule-producing strains of this series are among the strains which tend to be parasitic in their habits.

Blood-Agar Plate.-Recent workers agree concerning the value of the bloodagar plate for the separation of streptococci into two main groups, the hemolyzers and the nonhemolyzers. Different investigators have recommended various amounts of defibrinated blood for use in the agar plate. Shottmüller, who first used the blood-agar plate, recommended the use of $40 \%$ of defibrinated blood. Holman used $5 \%$; Blake found $10 \%$ satisfactory. Becker ${ }^{\circ}$ emphasizes the necessity of a standard blood agar, and favors as the standard the medium recommended by the committee on standard methods in water analysis. He recommends that $1 \mathrm{cc}$ of defibrinated blood be added to $6 \mathrm{cc}$ of agar. Brown ${ }^{4}$ considers $5 \%$ sufficient. Approximately $10 \%$ has been found satisfactory in this work. I agree with Blake that it is necessary to have the blood well mixed. A smaller amount than $10 \%$ may lead to confusion in recording the presence of green producing streptococci since after more than 24 hours these organisms may show a slight zone of hemolysis. This is particularly true if part of the plate contains a small amount of blood. This zone of slight hemolysis about a colony with a greenish zone at the periphery of the hemolytic zone, which is produced by many of the green-producing organisms when the plate is read at longer periods than 24 hours, corresponds closely with that described as the alpha type by Smith and Brown. ${ }^{10}$ It is important to take into consideration the temperature of the agar at the time when the blood is added. If the blood and agar remain above $40 \mathrm{C}$. for any considerable length of time, the mixture becomes brown. The green organisms are then slow in producing methemoglobin and may be mistaken for hemolyzers when after more than 24 hours some slight hemolysis is shown without any methemoglobin around the periphery of the zone of hemolysis or around the colony.

Hopkins and Lang ${ }^{11}$ point out that hemolysis depends on the depth of the medium at which the colony is grown. I have found that using approximately $10 \mathrm{cc}$ of agar and $1 \mathrm{cc}$ of blood in plating the depth of the medium in the ordinary petri dish has no noticeable effect on hemolysis if the agar and the blood are well mixed and not allowed to remain above $40 \mathrm{C}$. Hopkins and Lang state that they found all gradations of action on the blood-agar plate between complete hemolysis and no action at all. Their conflicting results as pointed out by Blake probably were due to making observations at variable times, from 1-3 days after plating.

The zone of hemolysis in this series of 134 strains of hemolytic streptococci was found to vary but little in size. The average diameter was about $2 \mathrm{~mm}$. This corresponds to the beta type of some writers. In one case in which at the time of swabbing the patient complained of a sore throat and showed an inflamed pharynx hemolytic streptococci were found which produced a very small zone of hemolysis. Hemolytic streptococci that produced a similar zone of hemolysis were isolated from the canal of an extracted tooth. Both of these strains, 14 and 155B, grew poorly on blood agar and in all other mediums. Strain 14 required at least 48 hours to produce any visible growth on any mediums. It has been under observation for more than a year and has not shown any variation in its method of growth. In carbo-

- München. med. Wchnschr., 1903, 50, pp. 849, 909.

- Jour. Infect. Dis., 1916, 19, p. 754.

10 Jour. Med. Research, 1915, 31, p. 455.

11 Jour. Infect. Dis., 1914, 15, p. 63. 
hydrate mediums these strains are regular in their fermentation reactions. Floyd and Wolbach ${ }^{12}$ state that the zone of hemolysis varied greatly in their series and that most of their cultures retained the hemolytic property for several weeks. A number lost this property after being cultivated for several months on blood serum medium. They decided that in general hemolysis among the streptococci is characteristic of pathogenic types. In no case in their series did nonhemolytic strains acquire the hemolytic property while under cultivation. No mention is made of the kind of blood used.

All of my 134 hemolytic strains, several of which are more than a year old, have remained constant in the production of hemolysis. Of the 15 strains which were grown at $37 \mathrm{C}$. on blood agar and ascitic fluid agar for 10 months, 7 were hemolyzers. At the end of 10 months when plated on blood agar hemolysis was produced as readily as at first. This is true of the strains grown on ascitic fluid agar as well as those grown on blood agar. Six of these strains at the end of 10 months were kept at icebox temperature for 5 months without being transferred. When plated out all of those strains which had been kept on blood were alive and produced hemolysis on the blood-agar plate. Four of these strains which had been kept on ascitic fluid agar were alive and produced hemolysis on the blood-agar plate.

Ruediger $^{13}$ has shown that hemolysis does not readily take place if glucose is present in the agar. Shigeki Shikiguchi ${ }^{14}$ has found that this power of glucose to retard hemolysis bears no relation to the amount of acid that is produced by the action of the streptococci on the glucose in the medium. Although little hemolysis takes place when $2 \%$ of glucose is present in the medium, the organism itself is not changed in its power to hemolyze. Strain 345 was grown on $2 \%$ glucose blood agar at $37 \mathrm{C}$. for 11 weeks. This strain was then plated on ordinary blood agar, and hemolysis occurred as readily as at first.

Two types of nonhemolytic streptococci, the methemoglobin producers and those indifferent on blood, are recognized by Lyall, ${ }^{15}$ Holman, Blake, Brown, and others. Lyall states that this division is sufficiently constant to justify grouping on this basis. He groups the fecal streptococci among the organisms inactive on the blood-agar plate. Brown ${ }^{4}$ calls these inactive strains the gamma type. Aschner ${ }^{3}$ found that streptococci which would not produce methemoglobin on human blood would produce methemoglobin on ox blood. Strain 6 , isolated from an ulcer on the abdomen of a dog, and strains 455 and 456, isolated from different commercial buttermilk tablets, are the only strains in the series of the 150 nonhemolytic strains which were inactive on blood when isolated. These 3 strains became active in producing methemoglobin after being grown on blood agar for from one to two generations. All the nonhemolytic strains isolated from human feces (17), all those isolated from milk (27), and all those isolated from horse feces (30) produced green colonies on the blood-agar plate and have continued to from time to time. The green about the colonies of some of these strains was faint, but after one or two transfers the green zone became typical.

Four strains of nonhemolyzers which had been grown on blood agar and on ascitic fluid agar for 10 months were then left in the icebox for 5 months without being transferred. The following results were obtained when these strains were plated out:

12 Jour. Med. Research, 1914, 29, p. 493

1s Jour. Infect. Dis., 1906, 3, p. 663.

14 Jour. Infect. Dis., 1917, 21, p. 475.

15 Jour. Med. Research, 1914, 30, pp. 487, 515. 
Strains 4, 5, 18, grown on blood agar .........green colonies

Strain $21 \ldots \ldots\left\{\begin{array}{l}\text { grown on ascitic fluid agar.... dead } \\ \text { grown on blood agar ........ indifferent } \\ \text { grown on ascitic fluid agar.... indifferent }\end{array}\right.$

Strain 21 was transferred but once when the colonies on the blood-agar plate showed the typical green zone again. The evidence is that all nonhemolytic strains of streptococci when grown on suitable mediums are methemoglobin producers.

\section{Distribution of Hemolytic Streptococci}

Although hemolytic streptococci are found in different places under apparently normal conditions as in the normal throat, milk, horse feces, and occasionally human feces, yet the fact still remains that acute processes such as septicemia and pyemia are generally caused by hemolytic streptococci. To what extent hemolytic organisms are pathogenic is still a question of considerable doubt. Some clinicians have accepted hemolysis as an indication of virulence. My 134 strains were collected from the following sources:

TABLE 2

Sources of Strains

\begin{tabular}{|c|c|}
\hline Normal throats.......... & 69 \\
\hline Removed tonsils......... & 18 \\
\hline 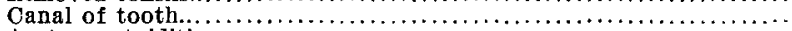 & 1 \\
\hline 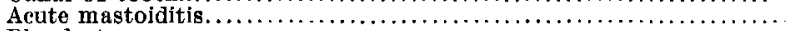 & 1 \\
\hline 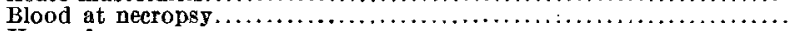 & 18 \\
\hline Horse feees. $\ldots \ldots \ldots \ldots \ldots \ldots \ldots \ldots \ldots \ldots \ldots \ldots \ldots \ldots \ldots \ldots \ldots \ldots \ldots$ & 10 \\
\hline 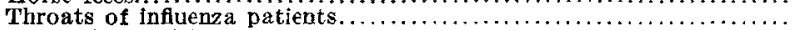 & 9 \\
\hline 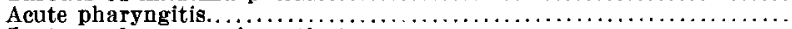 & 2 \\
\hline 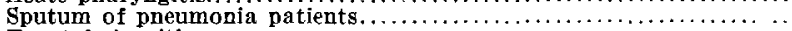 & 3 \\
\hline 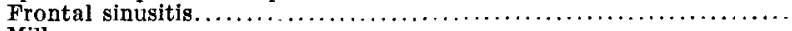 & ] \\
\hline 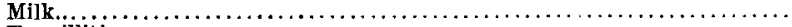 & 1 \\
\hline 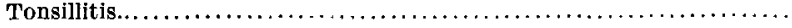 & 1 \\
\hline
\end{tabular}

Of these 134 strains, 79 were found in the normal throat and from horse feces. Several of those found in horse feces were tested and found to be pathogenic to rabbits. Several of the hemolyzers from the normal throat were tested for pathogenesis in rabbits, but death was not produced.

It is interesting to note the relative frequency of hemolytic streptococci in the normal throat. During the winter of 1917-1918 respiratory diseases, due apparently to hemolytic streptococci, were frequent in the army camps.

An epidemic of empyema following bronchopneumonia was reported by the Empyema Commission $^{16}$ at Camp Lee; hemolytic streptococci were isolated in pure cultures from the aspirated fluid. Irons ${ }^{17}$ found at Camp Custer in cases of empyema following measles that the exciting organism was Streptococcus hemolyticus. In a streptococcus epidemic at Camp Zachary Taylor, in which there were evidences of septicemia, an investigation was made by Fox and Hamburger ${ }^{18}$ to determine the portal of entry. Fifteen per cent. of the men of one contingent were found to be harboring hemolytic streptococci in the pharynx when they entered the camp. In one company which had been at the camp for 6 months the percentage of those carrying hemolytic streptococci in the pharynx was 85 . In the base hospital at Fort Riley $28.2 \%$ of the sputum of 428 cases of pneumonia contained hemolytic streptococci. Of the 155 cases of empyema, $68.4 \%$ were found to be produced by hemolytic

16 Jour. Am. Med. Assn., 1918, 71, p. 443.

17 Ibid., 1918, 70, p. 687.

1s Ibid., p. 1758. 
streptococci. Small ${ }^{18}$ found that nearly $25 \%$ of the sputum from the pneumonia patients examined between September, 1917, and April, 1918, at Camp Pike showed the presence of hemolytic streptococci. At Camp Dodge, Miller ${ }^{20}$ reported an epidemic of pneumonia and empyema due to streptococci. The exudates in 95 of these cases were examined bacteriologically, and 88 pure cultures of hemolytic streptococci were found. Smillie ${ }^{21}$ reported in 1907 that of 100 normal throats examined the beta type of hemolytic streptococci, according to Smith and Brown, was found in only one of the 100 throats.

The fact that some of these workers have found apparently normal individuals harboring the hemolytic streptococci in the pharynx, and the fact that these organisms were found in such a large number of individuals at the time and at the place of these epidemics, has led me to make observations on the relative frequency of hemolytic streptococci in the normal nasopharynx and on the normal tonsil.

The throats of 100 students at the University of Chicago were examined during the summer quarter of 1918. During the autumn quarter of 1918, another 100 throats were examined. Most of these students were medical students from the classes of bacteriology and pathology. Those who had lived in Chicago before the beginning of the quarter in which their throats were examined were classified as residents of Chicago; of these there were 117. The remaining 83 were from various states. The work was started shortly after June 16, 1918. One hundred and sixty of the students examined were males; ages ran from 20-40.

The nasopharynx was swabbed with a curved wire swab as recommended in the Standard Technique of Meningococcus Carrier Detection.22 Each tonsil was swabbed with a separate straight swab. Both tonsillar swabs were immediately put into about $3 \mathrm{cc}$ of sterile salt solution; the nasopharyngeal swab was put into a separate tube of salt solution. The content of these swabs was well mixed in the salt solution by stirring the swabs in the solution. The swabs were removed and the mixture of organisms was at once plated. Often only a few hemolytic colonies appeared, and these had to be replated to obtain them in pure culture.

Comparisons were made between the streak method on cooled and hardened blood-agar plates and dilutions. It was found that if hemolyzers were few they could be detected by the dilution method where they would be missed by the streaking method.

In every case where positive hemolyzers are reported the colony was picked from the plate and replated. The organism was then isolated and confirmed as a streptococcus morphologically and by Gram staining. Morphologic and staining confirmation seems to be necessary, as in many of the plates examined an organism was present at 24 hours' incubation which produced a slight hemolysis somewhat similar to that of some of the colonies of hemolytic streptococci. After about 48 hours these colonies become pyramidal in shape and show a milk-white color. Morphologically, the organism is biscuit-shaped diplococci. In staining by the Gram method the stain is not retained.

Thirty-seven per cent. of the students examined in the summer quarter and $36 \%$ of those examined in the fall quarter showed hemolytic streptococci in the nasopharynx or on the tonsil. Of the number examined, 34 had had tonsils removed; of these 8 contained hemolyzers. Of the 200 throats examined, 14 had somewhat enlarged tonsils; 7 of these showed hemolyzers. It is interesting to compare this with a series of 25 pairs of tonsils which were removed in the dispensary of Rush Medical School. These tonsils were collected under as aseptic conditions as possible and brought to the laboratory. The posterior portion of the tonsil was seared with a hot iron, and the tonsil was opened in the seared portion with a sterile scalpel. Part of the tonsillar pulp was removed and placed in a sterile petri dish. This material was macerated and later plated. Of these 25 pairs of tonsils, 17 pairs showed the presence of

19 Ibid., 1918, 71, p. 700.

20 Ibid., p. 702.

21 Jour. Infect. Dis., 1917, 20, p. 45.

22 Standard Technique of Meningococcus Carrier Detection, U. S. Army, 1918. 
hemolytic streptococci. It seems that the fact that the tonsils are enlarged does not indicate that the owner is surely harboring the hemolytic streptococci, and conversely the fact that the tonsils are removed does not indicate that the individual is free from hemolytic streptococci.

To determine in what manner the hemolytic flora varies from time to time 6 laboratory workers were selected. Swabs were made from once to twice a week for 12 weeks. Of these 6 persons, 3 were always free from hemolyzers, in 2 hemolyzers were always found, in one they were found every time except on one examination. It has been suggested that persons working or mingling with those who harbor the hemolyzers are apt to become carriers. Two of the 3 who never showed the presence of hemolyzers were present continually as instructors in the laboratory and in fairly close daily contact with individuals known to be harboring hemolytic streptococci.

The results obtained in this series of 200 throats justify the conclusion that a considerable number of healthy people are sometimes carriers of hemolytic streptococci.

Sherman ${ }^{23}$ examined the throats of 32 dogs. Typical hemolytic streptococci were found in $39 \%$. Poppins, working in this laboratory on the frequency of hemolytic streptococci in horse feces, found them present in $25 \%$ of the samples examined (personal communication). The hemolytic streptococci which are reported by me in the present series as being isolated from horse feces were isolated by him. Davis has frequently found hemolytic streptococci in milk. Out of 15 samples of pasteurized milk examined, I found 2 samples containing hemolytic streptococci.

\section{Distribution of Nonhemolytic Streptococci}

Nonhemolytic streptococci are found in almost any place where bacteria are present. These streptococci are normally present on the mucous membranes of the respiratory passages and in the intestinal canal. They were found in all the 200 throats and the 25 pairs of tonsils. They were present in the feces of the cow, horse and man in practically all determinations. Urine often contains these strains of nonhemolytic streptococci even when collected under aseptic conditions. Str. lacticus is present in commercial starters and in milk even when it is pasteurized. Heinemann found Str. lacticus on the skin of cows. He was able to raise the virulence of these organisms so that rabbits were killed when injected with doses of $0.1 \mathrm{cc}$ of a broth culture. These streptococci isolated from milk and commercial starters produce the typical green colony on the blood-agar plate.

\section{Fermentation Reactions}

Attempts to classify the streptococci by their power to ferment various carbohydrates were first made by Gordon ${ }^{24}$ in 1903 and $\mathrm{Hiss}^{7}$ in 1905. Hiss indicated a classification which divided the streptococci into groups. One group fermented only the monosaccharids, another fermented the disaccharids, and another fermented the polysaccharids as starch, dextrin and glycogen. Gordon's work, 1905, in which he used 9 different tests, has led to much investigation in regard to classification in relation to the distribution of streptococci.

28 Jour. Infect. Dis., 1919, 25, p. 259.

24 Lancet, 1905, 2, p. 1400. 
Andrewes and Horder, ${ }^{25}$ using Gordon's tests, tabulated 1,200 strains isolated from various sources. These strains of streptococci, including the pneumococci, were placed in 7 groups, Str. equinus, Str. mitis, Str. pyogenes, Str. salivarius, Str. anginosus, Str. fecalis, and the pneumococcus.

Beattie and Yates ${ }^{28}$ tested 42 strains of streptococci according to Gordon's tests and found these tests unreliable in their hands. The work of Floyd and Wolbach ${ }^{12}$ is unique in that they reported a large number of organisms which failed to ferment any of the carbohydrates. The number which failed to ferment lactose is especially large. They state that their fermentation groups were supported by immune reactions, agglutination, and complement fixation.

Lyall, ${ }^{\text {ts }}$ working with 263 strains and using the fermentation tests as suggested by Gordon in combination with the blood-agar plates, reported that it is possible to recognize all the groups proposed by Andrewes and Horder, and another group not reported by them, a group which is capable of fermenting salicin and raffinose. Lyall's hemolytic group presented the most constant carbohydrate reactions. Seventy-four and nine tenths per cent. of this group conformed to Str. pyogenes of Andrewes and Horder. Lyall states that the ability to ferment raffinose is characteristic of the methemoglobin-producing organisms. He separates the pneumococci from the other streptococci primarily on the basis of their ability to ferment inulin.

The conclusion was reached by Hopkins and Lang, ${ }^{11}$ after working with 105 strains, that streptococci occurring in severe infections of man may be differentiated from the saprophytic types by the fermentation tests. One pathogenic and six saprophytic groups are recognized. The pathogenic group differs from the six saprophytic groups in being able to ferment salicin and failing to ferment raffinose and mannite. These workers used the blood. agar plate, but did not consider it a reliable basis for classification.

Holman, using strains of his own collection and the data of others, reported the action on blood-agar plates and the fermentation reactions of 2,463 different strains of streptococci. He states that the constancy of these reactions is essential to the method of classification advocated and that evidence of transmutation or examples of inherent alteration of character have been insufficient to invalidate this method. He also concludes that the confusion in the results of the tests and the examples of so-called alteration are explained by the relative difficulty of growth and the morphologic similarity among different types. Holman makes 16 groups of streptococci on the basis of the reaction on the blood-agar plate and the various carbohydrates.

Blake's contribution to the classification of the streptococci, like Holman's, is based on observations with the blood-agar plate and the various fermentation reactions. $\mathrm{He}$ reduced the number of groups to four. He considers that the slight variation among the hemolytic organisms is not sufficient to demand separate classification. He divided the methemoglobin producers and those indifferent on the blood-agar plate into three groups, depending on their action on lactose and mannit.

Holman differs from Lyall and Blake in classifying hemolyzers, in that he separates them into eight groups mainly on the basis of the fermentation of the different carbohydrates. He at first divided them into two main groups on the basis of their lactose fermentation. This raises the question of the reliability of lactose fermentation.

Lactose Fermentation of Hemolytic Streptococci.-One hundred and fourteen of the 134 strains of hemolyzers always fermented lactose, Many of these strains have been tested from 2-6 times at intervals varying in duration from 3-15 months. Seven of these strains were grown on blood agar and ascitic fluid agar at $37 \mathrm{C}$. for 10 months. Twenty strains have at one or more times failed to ferment lactose. Only 4 of these 20 strains $(32,137,345,386)$ have always failed to ferment lactose at the end of the regular fermentation period of 5 days. Three of these strains $(137,345,386)$ were isolated from the normal throat and one (32) from the blood of a patient dying of carcinoma of the liver and pelvic abscess. Only two strains $(2,7)$, both of which were isolated from the blood at necropsy from different cases of pyemia, varied more than once in their lactose fermentation (table 1, strains 2,7 ).

2s Ibid., 1906, 2, pp. 708, 775, 852.

26 Jour. Path. and Bacteriol., 1911, 26, p. 247. 
It is interesting to consider strain 31 in relation to strain 32. Both of these strains were isolated from the same individual at necropsy. Strain 31 was isolated from the blood, and strain 32 was isolated from the pus of a pelvis abscess. Strain 31 fermented lactose on only one occasion after it had been grown on ascitic fluid agar for 10 months; strain 32 never fermented lactose at the end of the regular fermentation period of 5 days. To determine whether a continuous growth in lactose broth and a longer period of incubation would have any effect on the fermentation of lactose negative hemolytic streptococci strains 32, 137 and 386 were grown in lactose broth for eight weeks with weekly transfers. Seventeen days after the sixth weekly transfer these strains fermented lactose when litmus was used as an indicator. When Andrade was used as an indicator slight fermentation occurred at the end of seven days.

TABLE 3

Fermentation Reactions

\begin{tabular}{|c|c|c|c|c|c|}
\hline Strain & Lactose & Mannit & Salicin & Date & \\
\hline 2 & $\begin{array}{l}- \\
+ \\
+ \\
+ \\
+ \\
- \\
- \\
-\end{array}$ & $\begin{array}{l}= \\
= \\
= \\
= \\
= \\
=\end{array}$ & $\begin{array}{l}+ \\
+ \\
+ \\
+ \\
+ \\
+ \\
+\end{array}$ & $\begin{array}{r}11 / 22 / 17 \\
12 / 12 / 17 \\
1 / 2 / 18 \\
11 / 20 / 18 \\
12 / 10 / 18 \\
1 / 7 / 18 \\
10 / 8 / 18 \\
1 / 7 / 18 \\
10 / 7 / 18\end{array}$ & $\begin{array}{l}\text { Blood agar at } 37 \mathrm{C} . \\
\text { Blood agar at } 37 \mathrm{O} \text {. } \\
\text { Ascitic agar at } 37 \mathrm{C} \text {. } \\
\text { Ascitic agar at } 37 \mathrm{C} \text {. }\end{array}$ \\
\hline $7^{\circ}$ & $\begin{array}{l}+ \\
\pm \\
- \\
- \\
- \\
- \\
\pm\end{array}$ & $\begin{array}{l}= \\
= \\
= \\
= \\
= \\
=\end{array}$ & $\begin{array}{l}+ \\
+ \\
+ \\
+ \\
+ \\
+ \\
+ \\
+\end{array}$ & $\begin{array}{r}12 / 12 / 17 \\
12 / 18 / 17 \\
1 / 2 / 18 \\
3 / 12 / 18 \\
11 / 20 / 18 \\
12 / 10 / 18 \\
1 / 7 / 18 \\
10 / 7 / 18 \\
10 / 7 / 18 \\
10 / 7 / 18\end{array}$ & $\begin{array}{l}\text { Blood agar at } 37 \mathrm{C} \text {. } \\
\text { Blood agar at } 37 \mathrm{C} \text {. } \\
\text { Ascitic agar at } 37 \mathrm{C} \text {. } \\
\text { Aseitic agar at } 37 \mathrm{C} \text {. }\end{array}$ \\
\hline 80 & $\begin{array}{l}+ \\
+ \\
+ \\
+ \\
+\end{array}$ & $\begin{array}{l}\frac{-}{+} \\
\frac{+}{+} \\
+\end{array}$ & $\begin{array}{l}+ \\
+ \\
+ \\
+ \\
+\end{array}$ & $\begin{array}{r}3 / 4 / 18 \\
4 / 28 / 18 \\
11 / 25 / 18 \\
11 / 26 / 18 \\
1 / 9 / 18\end{array}$ & \\
\hline
\end{tabular}

Strain 406 was irregular in its lactose fermentation. To determine to what extent the variation continued, this strain was plated out on blood agar. Ten colonies were picked off and put into separate lactose broth tubes. All of these tubes were fermented in 24 hours except two (1 and 10), which were but slightly fermented in 48 hours. Number 1 was then plated out and 20 separate colonies were picked off and inoculated into lactose broth tubes. All of these tubes of lactose were fermented but number 10 . This one remained lactose negative for 5 days. Tube number 10 was then plated out and 10 colonies were picked and inoculated into 10 lactose broth tubes. All of these tubes of lactose broth were acidified in 24 hours except number 5 , which fermented lactose in 48 hours. Tube 10 in the first plating was plated in blood agar. Four colonies were picked and inoculated into lactose broth tubes. All of these were fermented in 5 days except tube 3 . Tube 3 was then plated and 10 colonies were picked off and inoculated into lactose broth. All of these 10 tubes were fermented except tube 6 . This tube was plated in blood agar and 3 colonies picked. Of these 3 tubes, number one fermented lactose in 3 days, number two 
in 1 day, and number three in 2 days. Tube number one was plated out on blood agar and 10 colonies were picked off and put into lactose broth. All of these tubes fermented lactose except number 6, which failed to ferment lactose at all, and number 10, which fermented lactose after 3 days. In each negative tube growth was determined by plating. In all, 67 tubes of the same lot of lactose broth were tested in this experiment, and in 4 of these fermentation failed to occur in 5 days. On this test alone the organism might have been placed in either of 2 groups.

Mannite Fermentation of Hemolytic Streptococci--The lactose positive and the lactose negative organisms are divided further by Holman on the basis of their ability to ferment mannite. Of the 134 hemolyzers in my series, 10 fermented mannite at least on one titration. Of these 10 , only 2 strains $(67,371)$ fermented mannite on each titration. One of these was isolated from a removed tonsil, and the other from the normal throat. Both of these organisms would be classified as Str. infrequens according to Holman's classification. Only one strain (80) varied in its mannite fermentation more than once (table 1 , strain 80).

Salicin Fermentation of Hemolytic Streptococci.-Holman divides the mannite fermenters and the mannite nonfermenters into separate groups on the basis of ability to ferment salicin. This brings up the reliability and constancy of the fermentation of salicin as a basis for classification. Of the 134 strains of hemolyzers tested by me, 5 strains $(32,40,137,174,345)$ failed to ferment salicin at one or more titrations. Three of these $(137,174,345)$ failed to ferment salicin at every titration. Comparison between lactose and salicin fermentation shows that all those strains which are irregular or fail to ferment salicin are either weak in their ability to ferment lactose or fail altogether. to ferment it. Strains 32, 137 and 345, which always failed to ferment salicin, also failed to ferment lactose during the regular fermentation period. Strain 40 fermented lactose once out of 5 determinations. Strain 174 fermented lactose once out of 4 determinations. In all these determinations growth in the tube from which the test sugars were inoculated was confirmed by the fact that good growth occurred in the saccharose tube and the milk. Strain 32 was isolated from a pelvic abscess; strain 40 was isolated from the blood of a patient dying with carcinoma of the pharynx; strains $137,174,345$ were isolated from the normal throat. In noting this it must be taken into consideration that 67 other strains which were isolated from the normal throat did ferment salicin.

Grouping of Hemolytic Streptococci.-According to Holman's nomenclature, 30 strains of the 134 hemolyzers could not be classified as Str. pyogenes at every titration. All of the 30 strains except $7(61,137,345,371,386,32,174)$, however, did fall into the group Str. pyogenes at one or more determinations.

The class Str. infrequens is characterized by being a positive fermenter of lactose, mannite and salicin. It differs from the ordinary pyogenes only in being able to ferment mannite. Ruediger ${ }^{27}$ has found this type associated with scarlatinal angina. He also found this type in normal throats, in throats of tonsillitis patients, in middle-ear infections, erysipelas and cellulitis; in the pericardial cavity, in blood in puerperal sepsis, in conjunctivitis, sinusitis, and in the throats of patients having measles. Of the 9 strains $(61,78,80,81,91$, $104,112,155 \mathrm{~B}, 371)$ falling into Str. infrequens all except two $(61,371)$ on one or more titrations would fall back into the pyogenes class. Strain 61 is the only one of 19 strains isolated from removed tonsils which would always be

27 Amer. Jour. Pub. Health, 1912, 2, p. 107. 
placed in the class of Str. infrequens. Strain 371 is the only one of 69 strains isolated from the normal throat which would always fall into the infrequens group.

None of my strains would fall permanently into Str. hemolyticus I, II, or III, according to Holman's nomenclature. Strain 36 isolated from the pus of a frontal sinusitis would be grouped as Str. hemolyticus II once out of its 5 titrations. In the other 4 titrations it would be grouped as Str. pyogenes once and as Str. equi three times. One strain (83) isolated from a removed tonsil would fall into Str. hemolyticus II once out of 4 of its determinations. In the other 3 titrations it would be grouped as Str. pyogenes.

One strain (174) isolated from the swab from a cryptic tonsil where there had never been a history of sore throat would fall into Str. anginosus once out of three of its titrations. In the other 2 titrations it would be classified as Str. subacidus.

Sixteen strains would fall into group Str. equi. Of these, 14 during one or more titrations could be grouped as pyogenes, one (36) as hemolyticus II, and 2 $(32,40)$ as subacidus. One strain (386) remained true on each titration as Str. equi. It is interesting to note the source of these organisms which at one time or another could be grouped as Str. equi. This group has been considered as representing those' strains which in one way or another are associated with the horse. The one strain remaining true to this group in all determinations was isolated from the normal throat. Two of the 16 strains which would be grouped as Str. equi, strains 403 and 406 , were isolated from horse feces. Strain 403 fermented lactose two times out of 3 titrations, and 406 fermented lactose once out of 2 titrations. It is interesting to note that of the 10 hemolytic strains isolated from horse feces these two strains are the only two which at any time failed to ferment lactose. All other strains falling into the group Str. equi are from septicemia, removed tonsils, or normal throats. The source of these strains would not seem to suggest that they should be classified with those organisms obtained from horse feces. The strains isolated from horse feces were tested on rabbits and found to be pathogenic, killing in 4 days when $1 / 10 \mathrm{c} c$ of a 24 -hour broth culture was injected intravenously.

Strains 137 and 345 always were grouped as Str. subacidus. Three strains $(32,40,174)$ fell into this group in one or more determinations. This group was called subacidus by Holman because it failed to ferment any of the sugars except glucose and saccharose. Floyd and Wolbach have reported a large number of strains belonging to this group. The sources such as bronchopneumonia and scarlet fever from which Floyd and Wolbach isolated their organisms would place them in as pathogenic a group as Str. pyogenes. Strains 137 and 345 were isolated from the normal throat.

Of the 134 hemolytic strains which cover a variety of sources, only 6 strains in all tests failed to group themselves as Str. pyogenes according to Holman's classification; that is, they failed to follow the usual order of fermentation to hemolytic streptococci in fermenting lactose and salicin but not fermenting mannite or raffinose. The sources of these 6 strains, 5 from the throat and 1 from septicemia, show no significance of relationship to their fermentation reactions. Thus it seems that Blake is justified in his decision that the slight variation among hemolytic organisms is not sufficient to demand a separate classification.

Lactose Fermentation of Nonhemolytic Streptococci-As among the hemolyzers slight variation occurs among the nonhemolyzers in the fermentation of lactose. All except 16 of the 150 strains of nonhemolyzers reported in this 
series fermented lactose at every determination. Five of these 16 strains (189, $211,213,440,466$ ) never fermented lactose in any of their determinations. The sources of these strains which always failed to ferment lactose are as follows: strain 189 from the normal throat, strains 211, 213, 440, 446 from horse feces. Only two strains $(86,87)$ varied in their lactose fermentation more than once (table 4 , strains 86,87 ).

TABLE 4

Fermentation Reactions

\begin{tabular}{|c|c|c|c|c|c|c|}
\hline Strain & Luctose & Mannite & Raffinose & Salicin & Date & \\
\hline 4 & $\begin{array}{l}+ \\
+ \\
+ \\
+ \\
+\end{array}$ & $\begin{array}{c}- \\
- \\
-\end{array}$ & $\begin{array}{l}+ \\
+ \\
+ \\
- \\
-\end{array}$ & - & $\begin{array}{r}10 / 21 / 17 \\
12 / 18 / 17 \\
1 / 2 / 18 \\
5 / 11 / 18 \\
11 / 20 / 18\end{array}$ & \\
\hline 10 & $\begin{array}{l}+ \\
+ \\
+ \\
+ \\
+ \\
+ \\
+ \\
+ \\
+\end{array}$ & $\begin{array}{l}+ \\
+ \\
\frac{+}{+} \\
\frac{t}{t}\end{array}$ & $\begin{array}{l}- \\
- \\
- \\
- \\
-\end{array}$ & $\begin{array}{l}+ \\
+ \\
+ \\
+\end{array}$ & $\begin{array}{r}12 / 12 / 17 \\
12 / 18 / 17 \\
1 / 2 / 18 \\
11 / 20 / 18 \\
1 / 7 / 18 \\
10 / 7 / 18 \\
1 / 7 / 18 \\
10 / 7 / 18\end{array}$ & $\begin{array}{l}\text { Blood agar } 37 \mathrm{C} . \\
\text { Blood agar } 37 \mathrm{C} . \\
\text { Ascitic agar } 37 \mathrm{C} \text {. } \\
\text { Ascitic agar } 37 \mathrm{C} \text {. }\end{array}$ \\
\hline 20 & $\begin{array}{l}+ \\
+ \\
+ \\
+ \\
+ \\
+ \\
+\end{array}$ & $\begin{array}{l}+ \\
+ \\
+ \\
+ \\
+ \\
+\end{array}$ & $\begin{array}{l}- \\
- \\
- \\
-\end{array}$ & $\begin{array}{l}+ \\
+ \\
+\end{array}$ & $\begin{array}{r}12 / 31 / 17 \\
3 / 11 / 18 \\
1 / 20 / 18 \\
1 / 7 / 18 \\
10 / 7 / 18 \\
1 / 7 / 18 \\
10 / 7 / 18\end{array}$ & $\begin{array}{l}\text { Blood agar } 37 \mathrm{C} \text {. } \\
\text { Blood agar } 37 \mathrm{C} \text {. } \\
\text { Ascitie agar } 37 \mathrm{C} \text {. } \\
\text { Ascitic agar } 37 \mathrm{C} \text {. }\end{array}$ \\
\hline 86 & $\begin{array}{l}+ \\
+ \\
-\end{array}$ & $\begin{array}{l}+ \\
\therefore \\
\therefore\end{array}$ & $\begin{array}{l}- \\
- \\
-\end{array}$ & $\overline{+}$ & $\begin{array}{r}3 / 6 / 18 \\
4 / 28 / 18 \\
11 / 22 / 18 \\
12 / 19 / 18\end{array}$ & \\
\hline 87 & $\begin{array}{l}+ \\
+ \\
-\end{array}$ & $\begin{array}{l}- \\
-\end{array}$ & $\begin{array}{l}+ \\
+ \\
-\end{array}$ & + & $\begin{array}{r}3 / 7 / 18 \\
4 / 28 / 18 \\
11 / 25 / 18 \\
12 / 19 / 18\end{array}$ & \\
\hline 88 & $\begin{array}{l}+ \\
+ \\
+\end{array}$ & 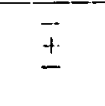 & $\overline{-}$ & $\frac{+}{-}$ & $\begin{array}{r}3 / 6 / 18 \\
4 / 28 / 18 \\
11 / 25 / 18 \\
12 / 9 / 18\end{array}$ & \\
\hline
\end{tabular}

Mannite Fermentation of Nonhemolytic Streptococci.-Forty-two strains of the 150 nonhemolyzers fermented mannite one or more times during the various determinations; 36 of the 42 fermented it at each titration. Only two strains $(10,20)$ varied in their ability to ferment mannite more than once (table 4 , strains 10,20 ).

Salicin Fermentation of Nonhemolytic Streptococci-Eighty-seven of the 150 nonhemolyzers fermented salicin; 12 of the 87 were irregular in their fermentation of salicin, but at no time did any of the strains vary more than once. Lyall states that all streptococci which are indifferent on blood agar are salicin fermenters. In his indifferent group he places the strains isolated from fecal sources. It has not been found that all of the strains of fecal origin in this series of 150 nonhemolyzers ferment salicin. Of the 24 strains isolated from horse feces, 14 strains fermented salicin. All of the 16 strains isolated 
from human feces did ferment salicin. The 27 strains isolated from milk - a material which might easily be contaminated with fecal matter - fermented salicin. Of the 67 strains of fecal origin, 57 were positive salicin fermenters.

Rafinose Fermentation of Nonhemolytic Streptococci.-Lyall ${ }^{15}$ states that all the methemoglobin producers are raffinose fermenters. Blake considers the fermentation of raffinose unimportant since it so nearly coincides with the fermentation of inulin. All of the methemoglobin producers among the 150 strains are not raffinose fermenters. Only 50 strains at one or more times fermented raffinose. Eight of these positive raffinose fermenters showed a variation in their raffinose fermenting ability, but only three of these variable strains $(4,87,88$ ) varied more than once (table 2 , strains $4,87,88$ ). One of these raffinose fermenters was isolated from an infection on the face, 1 from a lung abscess of a cow, 1 from the blood of a patient dying with peritonitis, 1 from a pus pocket at the root of a tooth, 4 from removed tonsils, 5 from the normal throat, 17 from horse feces, 3 from human feces, and 1 from a buttermilk tablet. A greater proportion of those isolated from horse feces fermented raffinose than those isolated from any other source. Andrewes and Horder have two classes, Str. salivarius and Str. anginosus, which are reported as raffinose fermenters. Of the 60 strains isolated from the normal throat or removed tonsils, 19 fermented raffinose. This is a somewhat lower percentage of raffinose fermenters than is found among those strains isolated from horse feces. Twenty of the 40 strains isolated from feces (horse and human) fermented raffinose. There does not seem to be any direct relationship between the source of organism and their fermentation of raffinose unless it is that streptococci of fecal origin are often stronger raffinose fermenters than those strains isolated from other sources.

Grouping of Nonhemolytic Streptococci--Thirty-one strains of the 150 nonhemolytic strains on every determination fell into the group Str. fecalis according to Holman since they were positive fermenters of lactose, mannite, and salicin. Eight of these 31 strains were from human feces, but these 8 were only one half of the strains isolated from human feces. Depending on their salicin fermentation, the other 8 strains from human feces would be classified either as Str. mitis or Str. salivarius. Eight of the 24 strains isolated from horse feces fell into group Str. fecalis on every determination. Depending on their salicin fermentation, 13 other strains from horse feces would be classified either as Str. mitis or salivarius. The remaining 3 strains from horse feces could be grouped as follows: Strain 441 varied in its lactose fermentation and could be placed in the salivarius group twice and the ignavus group once; strain 440 being lactose, mannite, and salicin negative could be grouped as ignavus, and strain 433 was lactose and mannite positive and salicin negative, and would fall into group Str. nonhemolyticus I.

Thirteen of the 31 strain isolated from milk or milk products always fell into the fecalis group. The remaining 17 milk strains could be placed in the mitis or salivarius group. Three strains $(6,24,109)$ frow pathologic processes were always grouped as fecalis. Nine other strains were irregular in their fermentation reactions and fell into Str. fecalis one or more times. Only one (434) was of fecal origin. The remaining 8 were mostly from pathologic processes. These irregular strains could be classified in other groups according to Holman as follows: strain 10 as Str. mitis 3, of 8 determinations; strain 18 as mitis, 5 of 7 determinations; strain 20 as mitis, 5 of 7 determinations; strain 60 as mitis, 2 of 3 determinations. Strain 86 on account of its irregularity in lactose, mannite and salicin fell one or more times into all of Holman's 
8 groups of nonhemolyzers; strain 88 could be placed in the groups fecalis, nonhemolyticus I, mitis, and salivarius; strain 3 fell into mitis once in two determinations, and strains 121 and 434 could be grouped as mitis in 2 of 3 of their determinations.

Blake states that it has been thoroughly established that the majority of streptococci from the intestinal tract of man are characterized by the fermentation of mannite. This statement is not entirely borne out by the findings of workers who have studied the fecal streptococci. Houston ${ }^{23}$ studied 300 strains isolated from human feces and found 73 of them capable of fermenting mannite. Holman reported in all 39 strains isolated from feces. Twenty-four of these fermented mannite. Buerger reported 5 strains from the stools of patients having diarrhea. Three fermented mannite. The results of these workers agree with my findings in showing that a high percentage of nonhemolytic streptococci isolated from human feces do not ferment mannite.

It is interesting to consider the source of the strains reported by various workers as grouping as Str. fecalis. Andrewes and Horder ${ }^{2}$ reporțed that $21 \%$ of their strains isolated from pathologic sources fermented mannite. Holman, combining his findings with those of Andrewes and Horder, Hopkins and Lang, Kligler, Hartzell and Henrici, and Broadhurst, reported 298 strains of nonhemolyzers which grouped as Str. fecalis. Of these 298 strains, 24 were from human feces, 1 from horse feces, 2 from the intestinal canal of the guinea-pig, 13 from the intestines of the dog, 19 from the feces of the dog, 15 from the intestines of the cat. This shows that of the 298 strains reported by these workers as fermenting mannite, only 74 , or less than $25 \%$, were from fecal sources. The remaining 244 strains were isolated from such sources as milk, urine, blood, peritoneal cavity, throat (human, dog and cat), water, abdominal wall, abscesses and ulcers, osteomyelitis, pleural cavity, ear, pyorrhea, infarct of spleen, stump of leg, compound fracture, burn, pus, cellulitis, gallbladder, uterus and vagina of guinea-pig, esophagus and stomach of the $\operatorname{dog}$ and cat, and subcutaneous tissue of the frog.

A group of organisms could not well have a greater variety of sources. Broadhurst ${ }^{20}$ reported 120 strains which were isolated from the alimentary tract of dog and cat which fermented mannite. Seventy-three of these strains were isolated from the throat, esophagus and stomach. Blake reported only four strains belonging to this group, all of which were from pathologic processes. Considering the low percentage of fecal streptococci grouping in this group and the wide limits from which organisms grouping as Str. fecalis may be isolated, it seems that such grouping carries little significance in respect to indicating the source of the organisms falling into this group.

One strain (433) grouped permanently as Str. nonhemolyticus I. This strain was isolated from horse feces. Strains 86 and 88 fell into this group on one titration. No strains could be grouped permanently as Str. nonhemolyticus II or III.

Three strains $(211,213,466)$ were always negative in their lactose and mannite fermentation and positive in salicin fermentation, which placed them as Str. equinus according to Holman. They were isolated from horse feces. These are the only strains of the 24 isolated from horse feces which grouped as equinus. Strains 86,92 and 173 , which are irregular, fell into this group at times. Blake agrees with Holman in thinking that the relationship between

23 Supplement Annual Report Local Government Board, 1904-5, p. 327.

20 Jour. Infect. Dis., 1915, 17, p. 277. 
grouping and specific fermentation of lactose and mannite is sufficient to justify calling nonhemolytic strains of streptococci which have a close association with the horse Str. equinus.

Andrewes and Horder reported 95 noninulin fermenting strains conforming to what they called class Str. equinus. Seventeen of these 95 strains were isolated from saliva, 23 from human feces, and 1 from urine. The remaining 54 strains were obtained mainly from air, dust, and horse dung. Buerger's ${ }^{30}$ results agree in general with the other workers on the fermentation reactions of streptococci. His group, which only fails to ferment inulin and lactose, corresponds with Andrewes and Horder's class Str. equinus. Of his 33 strains isolated from different sources, he reported 2 strains which could be grouped as equinus. These strains represent 2 of 5 isolated from the stools of patients suffering from diarrhea. Holman, including his own series and those of other workers, reported 42 strains grouping as equinus. None of these were isolated from horse feces. He states that the sources often suggest air contamination. These 42 strains were isolated from such sources as normal throat, pyorrhea, human feces, urine and urethra, heart valves, blood, infected foot, hay, tonsils, milk, appendix, fractured clavicle, peritoneum of guinea-pig, and guinea-pig blood. Blake has reported but one strain, which was isolated from the tonsil of a diphtheria patient. Considering the few strains grouping as Str. equinus, the possibility of variation in lactose fermentation, the wide variation of sources of strains grouping as equinus, and the low percentage of strains from horse feces in this class, it is doubtful whether such nomenclature is very fortunate.

Two strains $(189,440)$ failed to ferment lactose, mannite, and salicin in all their determinations, and according to Holman, would be grouped as Str. ignavus. Ten other strains grouped as ignavus in one or more of their titrations, but fell back into mitis or salivarius. These strains in Str. ignavus, as in Holman's other small groups, show no relationship between source and fermentation.

Of the 150 nonhemolytic strains, 112 always grouped as Str. mitis or salivarius. Eighteen of the 38 nonhemolyzers which did not always group as mitis or salivarius fell into one or the other of these groups on one or more determinations. On the basis of salicin fermentation there are 11 strains which may be placed in either of these groups.

Blake differs from Holman in not considering salicin of significance. By this he eliminates all of Holman's lactose negative groups except Str. equinus. From the standpoint of the fermentation of mannite and salicin, according to my series, Blake is not justified in omitting salicin. From the standpoint of the relationship of source and fermentation reactions, he is not only justified in omitting salicin, but he may just as fairly omit the mannite and lactose and consider the few strains which will not ferment lactose as strains which show a variation from the main type. It has been observed that those strains failing to ferment lactose are feeble in their growth in other mediums. By omitting salicin fermentation, as Blake does, he places the two large groups, mitis and salivarius, in one group, Str. buccalis. This seems reasonable, since the relationship between source, pathogenesis and fermentation reactions of these throat organisms cannot be established in my series. If we eliminate the significance of the occasional failure to ferment lactose and the significance of salicin fermentation, the only two groups of the nonhemolytic streptococci remaining would be Str. buccalis and fecalis. This division is made on the basis of

so Jour. Exper. Med., 1907, 9, p. 428. 
mannite fermentation. While the relationship between source and the fermentation of mannite seems to be noticeable in the group classified as Str. fecalis by Holman and Blake, yet it is a question whether this relationship is sufficient to make a separate group.

\section{IMMUNE REACTION}

Agglutination.-In the work on streptococci, Floyd and Wolbach ${ }^{12}$ report that they found the 6 groups of streptococci, which they established on the basis of fermentations, were borne out by agglutination as well as by complement fixation. Kligler's ${ }^{31}$ results differ from Floyd and Wolbach's. He reported agglutination tests with 60 strains isolated mostly from pathologic processes. He concluded that agglutination did not separate streptococci into large groups; that classification on the basis of hemolysis was not confirmed by agglutination; that classification on the basis of fermentation reactions seemed to coincide more nearly with agglutination tests. For the agglutination tests which are reported in this paper the serum was titrated and found.to produce complete agglutination at dilutions of $1: 360$ in 4 hours. Two hours of incubation in the water bath at $37 \mathrm{C}$. followed by 2 hours at room temperature was the period of incubation adopted. Low dilutions $(1: 50)$ were used. Controls were made with normal serum and with uninoculated broth to guard against spontaneous agglutination which is common among streptococci and against any possible precipitation which might be produced as a result of inoculating the animals with broth cultures. Thirteen serums were used in the various agglutination tests. Nine of these $(2,372,368,399,367,411,371,345,174)$ were produced with hemolytic streptococci and five with nonhemolytic $(425,158,416,4,115)$.

Twenty-seven hemolytic organisms were tested with the 9 hemolytic serums. Twenty-seven other hemolytic organisms were tested with 4 hemolytic serums $(372,368, \cdot 399,367)$. This represents in all 351 agglutination tests between suspensions and serums of hemolytic organisms. Of these 351 tests, 64 , or $18 \%$, failed to agglutinate. The same 27 hemolytic organisms were also tested with 5 serums of nonhemolytic origin. Of the 135 tests represented in agglutinating the hemolytic serums with the nonhemolytic suspensions, 126 , or $93 \%$, failed to agglutinate.

Twenty-five nonhemolytic organisms were tested with the five nonhemolytic serums. Of the 125 tests represented in this series of nonhemolytic serums with nonhemolytic suspensions, 111 , or about $89 \%$, failed to give positive agglutinations. These 25 nonhemolytic suspensions were further tested with the 9 hemolytic serums, and in the 225 tests, 145 , or $64 \%$, failed to bring about agglutination.

The relative frequency of agglutination in the hemolytic and nonhemolytic groups in these series may be summarized as follows:

Hemolytic serum plus hemolytic streptococci........ $18 \%$ failure

Hemolytic serum plus nonhemolytic streptococci..... $64 \%$ failure

Nonhemolytic serum plus nonhemolytic streptococci... 89\% failure

Nonhemolytic serum plus hemolytic streptococci..... 93\% failure

These results seem to show that agglutination between hemolytic serum and hemolytic streptococci is relatively constant, that less than one half of the tests with hemolytic serum, and nonhemolytic streptococci show agglutination, that with nonhemolytic serum and other strain of hemolytic streptococci agglutination is infrequent, and that with nonhemolytic serum and hemolytic organ-

s1 Jour. Infect. Dis., 1915,16, p. 327. 
isms the agglutination is less frequent. Each serum whether hemolytic or nonhemolytic when tested with its homologous suspension gave typical agglutination.

Complement Fixation.-Floyd and Wolbach ${ }^{12}$ tested antigens prepared from six groups of streptococci with the serum of each group. They found in general that complement was fixed when each group was tested with its specific serum, but no fixation occurred when the serum of the other groups were used. Katharine Howell ${ }^{32}$ tested 65 strains (28 hemolyzers and 37 nonhemolyzers) with 28 antiserums. She prepared the antigens by washing the cells in salt solution and heating them at $56 \mathrm{C}$. for 30 minutes. She decided that no correlation existed between complement fixation and groups based on disease; that nonhemolytic antiserums gave less specific complement fixation reactions than hemolytic serums; that the organisms giving positive fixation could not be grouped in any way that would justify a classification of streptococci based on complement fixation. Kinsella and Swift, found a difference between hemolytic and nonhemolytic groups in their complement fixing properties. They considered that the first group was homogemeous, since nearly all these strains reacted in almost an identical way with hemolytic antiserums in their fixation reactions. They regarded the nonhemolytic streptococci as a heterogeneous group and represented it as possessing a right-handed element which would not fix complement with hemolytic serums and a left-handed element which would fix complement with hemolytic serums.

In my work the technic of Kinsella and Swift was followed except that $0.1 \mathrm{c} c$ instead of $0.05 \mathrm{cc}$ of antigen was used. Controls were made with broth as antigen to guard against complement fixation resulting from the possible presence in the antigen of protein from the broth. Such complement fixation might occur if antihodies against the protein in the broth were present in the serum as a result of injecting broth cultures in immunizing the animals. Seventeen animals were immunized against 17 different strains, respectively. Twelve strains $(367,372,368,389,381,345,174,386,2,32,14,411)$ were hemolyzers, five $(416,158,4,115,425)$ nonhemolyzers.

The 12 hemolytic serums were tested against 15 antigens prepared from hemolytic organisms $(367,174,345,386,371,352,177,166,159,411,14,2,30$, 32,38 ) (table 5). All of the 180 tests showed complete inhibition of hemolysis in $0.1 \mathrm{c} \mathrm{c}$ of the serum except in 4 , or $2 \%$ of the tests. Three of these failures were with serum 32. This organism was isolated from the blood of a case of septicemia. One of the antigens (2), with which serum 32 failed to fix, was also from a case of septicemia. The other two antigens which failed to fix complement with serum 32 were from organisms from the normal throat, but 7 of the 9 antigens from organisms from the normal throat fixed complement with serum 32: Three antigens from septicemia other than strain 2 fixed complement with antiserum 32. The fourth failure between hemolytic serum and hemolytic antigens to fix was antiserum 371 with antigen 367 , both from organisms from the normal throat. Thirty, or $16 \%$, of the tests with hemolytic antiserums and antigens failed to fix complement with $0.05 \mathrm{cc}$ of serum. Sixteen of these failures were with antigens of mouth origin and serum developed with organisms isolated from cases of septicemia or with organisms from the mouth and antigens of septicemia origin. When it is taken into consideration that in all these tests with hemolytic antiserum and antigens, there were only two serums and four antigens of septicemia origin, it is seen that failure to fix complement is much greater between the throat group and the septicemia group than it is in these groups themselves.

s2 Ibid., 1918, 22, p. 230. 
TABLE 5

Complement Fixation

\begin{tabular}{|c|c|c|c|c|c|c|c|c|c|c|c|c|c|c|c|c|}
\hline \multirow{2}{*}{$\underset{\text { (hemolytic) }}{\text { Antiserum }}$} & \multirow{2}{*}{$\begin{array}{l}\text { Dilution } \\
\text { of Serum } \\
\text { in c c }\end{array}$} & \multicolumn{15}{|c|}{ Hemolytic Antigens } \\
\hline & & 367 & 38 & 32 & 30 & 2 & 174 & 345 & 411 & 386 & 371 & 152) & 14 & 177 & 166 & 159 \\
\hline 367 & $\begin{array}{l}.1 \\
.05 \\
.025\end{array}$ & $\begin{array}{l}+ \\
+ \\
+\end{array}$ & $\begin{array}{l}+ \\
+ \\
+\end{array}$ & $\begin{array}{l}+ \\
+ \\
+\end{array}$ & $\frac{+}{-}$ & $\begin{array}{l}+ \\
+ \\
+\end{array}$ & $\begin{array}{l}+ \\
+ \\
+\end{array}$ & $\begin{array}{l}+ \\
+ \\
+\end{array}$ & $\begin{array}{l}+ \\
+ \\
+\end{array}$ & $\begin{array}{l}+ \\
+ \\
+\end{array}$ & $\begin{array}{l}+ \\
+ \\
+\end{array}$ & $\begin{array}{l}+ \\
+ \\
+\end{array}$ & $\begin{array}{l}+ \\
+ \\
+\end{array}$ & $\begin{array}{l}+ \\
+ \\
+\end{array}$ & $\begin{array}{l}+ \\
+ \\
+\end{array}$ & $\begin{array}{l}+ \\
+ \\
+\end{array}$ \\
\hline 372 & $\begin{array}{l}.1 \\
.05 \\
.025\end{array}$ & $\begin{array}{l}+ \\
+ \\
+\end{array}$ & $\begin{array}{l}+ \\
+ \\
+\end{array}$ & $\underline{+}$ & $\begin{array}{l}+ \\
+ \\
+\end{array}$ & $\frac{+}{-}$ & $\begin{array}{l}+ \\
+ \\
+\end{array}$ & $\begin{array}{l}+ \\
+ \\
+\end{array}$ & $\begin{array}{l}+ \\
+ \\
+\end{array}$ & $\begin{array}{l}+ \\
+ \\
+\end{array}$ & $\begin{array}{l}+ \\
+ \\
+\end{array}$ & $\begin{array}{l}+ \\
+ \\
-\end{array}$ & $\begin{array}{l}+ \\
+ \\
-\end{array}$ & $\begin{array}{l}+ \\
+ \\
+\end{array}$ & $\begin{array}{l}+ \\
+ \\
-\end{array}$ & $\begin{array}{l}+ \\
+ \\
+\end{array}$ \\
\hline 399 & $\begin{array}{l}.1 \\
.05 \\
.025\end{array}$ & $\begin{array}{l}+ \\
+ \\
+\end{array}$ & $\begin{array}{l}+ \\
+ \\
+\end{array}$ & $\begin{array}{l}+ \\
+ \\
+\end{array}$ & $\begin{array}{l}+ \\
+ \\
+\end{array}$ & $\begin{array}{l}+ \\
+\end{array}$ & $\begin{array}{l}+ \\
+ \\
+\end{array}$ & $\begin{array}{l}+ \\
+ \\
+\end{array}$ & $\begin{array}{l}+ \\
+ \\
+\end{array}$ & $\begin{array}{l}+ \\
+ \\
+\end{array}$ & $\begin{array}{l}+ \\
+ \\
+\end{array}$ & $\begin{array}{l}+ \\
+ \\
+\end{array}$ & $\begin{array}{l}+ \\
+ \\
+\end{array}$ & $\begin{array}{l}+ \\
+ \\
-\end{array}$ & $\begin{array}{l}+ \\
+\end{array}$ & $\begin{array}{l}+ \\
+ \\
+\end{array}$ \\
\hline 2 & $\begin{array}{l}.1 \\
.05 \\
.025\end{array}$ & $\frac{+}{-}$ & $\begin{array}{l}+ \\
+ \\
+\end{array}$ & $\begin{array}{l}t \\
+ \\
t\end{array}$ & $\begin{array}{l}+ \\
+ \\
+\end{array}$ & $\begin{array}{l}+ \\
+ \\
+\end{array}$ & $\begin{array}{l}+ \\
+ \\
-\end{array}$ & $\begin{array}{l}+ \\
+ \\
-\end{array}$ & $\begin{array}{l}+ \\
+ \\
+\end{array}$ & $\begin{array}{l}+ \\
+ \\
+\end{array}$ & $\begin{array}{l}+ \\
+ \\
+ \\
\end{array}$ & $\frac{+}{-}$ & $\begin{array}{l}+ \\
+ \\
+\end{array}$ & \pm & $\begin{array}{l}+ \\
+ \\
+\end{array}$ & $\begin{array}{l}+ \\
+ \\
+ \\
\end{array}$ \\
\hline 32 & $\begin{array}{l}.1 \\
.05 \\
025\end{array}$ & - & $\frac{ \pm}{-}$ & $\begin{array}{l}+ \\
+ \\
+\end{array}$ & $\frac{+}{-}$ & - & \pm & $\frac{+}{-}$ & $\begin{array}{l}+ \\
+ \\
+\end{array}$ & $\begin{array}{l}+ \\
+ \\
+\end{array}$ & $\begin{array}{l}+ \\
+ \\
-\end{array}$ & E & $\begin{array}{l} \pm \\
\pm\end{array}$ & $\begin{array}{l}+ \\
+ \\
+\end{array}$ & $\begin{array}{l}+ \\
+ \\
\end{array}$ & $\begin{array}{l}+ \\
+ \\
\end{array}$ \\
\hline 411 & $\begin{array}{l}.1 \\
.05 \\
.025\end{array}$ & $\frac{+}{-}$ & $\begin{array}{l}+ \\
+ \\
+\end{array}$ & $\begin{array}{l}+ \\
+ \\
+\end{array}$ & $\begin{array}{l}+ \\
+ \\
+\end{array}$ & $\begin{array}{l}+ \\
+ \\
+\end{array}$ & $\begin{array}{l}+ \\
+ \\
+\end{array}$ & $\begin{array}{l}+ \\
+ \\
+\end{array}$ & $\begin{array}{l}+ \\
+ \\
+\end{array}$ & $\begin{array}{l}+ \\
+ \\
+\end{array}$ & $\begin{array}{l}+ \\
+ \\
+\end{array}$ & $\begin{array}{l}+ \\
+ \\
+\end{array}$ & $\begin{array}{l}+ \\
+ \\
+\end{array}$ & $\begin{array}{l}+ \\
+ \\
+\end{array}$ & $\begin{array}{l}+ \\
+ \\
+\end{array}$ & $\begin{array}{l}+ \\
+ \\
+\end{array}$ \\
\hline 371 & $\begin{array}{l}.1 \\
.05 \\
.025\end{array}$ & - & $\begin{array}{l}+ \\
+ \\
+\end{array}$ & $\begin{array}{l}+ \\
+ \\
+\end{array}$ & $\begin{array}{l}+ \\
+ \\
+\end{array}$ & $\begin{array}{l}+ \\
+ \\
+\end{array}$ & $\begin{array}{l}+ \\
+ \\
+\end{array}$ & \pm & $\begin{array}{l}+ \\
+ \\
-\end{array}$ & $\begin{array}{l}+ \\
+ \\
-\end{array}$ & $\begin{array}{l}+ \\
+ \\
+\end{array}$ & $\begin{array}{l}+ \\
t \\
+\end{array}$ & $\begin{array}{l}+ \\
+ \\
+\end{array}$ & $\begin{array}{l}+ \\
+ \\
+\end{array}$ & $\begin{array}{l}+ \\
+ \\
+\end{array}$ & $\begin{array}{l}+ \\
+ \\
+\end{array}$ \\
\hline 345 & $\begin{array}{l}.1 \\
.05 \\
.025\end{array}$ & $\frac{+}{-}$ & $\begin{array}{l}+ \\
+ \\
+\end{array}$ & $\begin{array}{l}+ \\
+ \\
+\end{array}$ & $\begin{array}{l}+ \\
+ \\
+\end{array}$ & $\begin{array}{l}+ \\
+ \\
+\end{array}$ & $\begin{array}{l}+ \\
+ \\
+\end{array}$ & $\begin{array}{l}+ \\
+ \\
+\end{array}$ & $\begin{array}{l}+ \\
+\end{array}$ & $\begin{array}{l}+ \\
+ \\
-\end{array}$ & $\begin{array}{l}+ \\
+ \\
+\end{array}$ & $\begin{array}{l}+ \\
+ \\
+\end{array}$ & $\begin{array}{l}+ \\
+ \\
+\end{array}$ & $\begin{array}{l}+ \\
+ \\
+\end{array}$ & $\begin{array}{l}+ \\
+ \\
+\end{array}$ & $\begin{array}{l}+ \\
+ \\
+\end{array}$ \\
\hline 174 & $\begin{array}{c}.1 \\
05 \\
.025\end{array}$ & $\frac{+}{-}$ & $\begin{array}{l}+ \\
+ \\
-\end{array}$ & $\begin{array}{l}+ \\
+ \\
+\end{array}$ & $\begin{array}{l}+ \\
+ \\
+\end{array}$ & $\frac{+}{-}$ & $\begin{array}{l}+ \\
+ \\
+\end{array}$ & $\begin{array}{l}+ \\
+ \\
+\end{array}$ & $\begin{array}{l}+ \\
+\end{array}$ & $\begin{array}{l}+ \\
+ \\
+\end{array}$ & $\begin{array}{l}+ \\
+ \\
+\end{array}$ & $\begin{array}{l}+ \\
+ \\
+\end{array}$ & $\begin{array}{l}+ \\
+ \\
+\end{array}$ & $\begin{array}{l}+ \\
+ \\
+\end{array}$ & $\frac{+}{+}$ & $\begin{array}{l}+ \\
+ \\
+\end{array}$ \\
\hline 886 & $\begin{array}{l}.1 \\
.05 \\
.025\end{array}$ & $\frac{+}{-}$ & $\begin{array}{l}+ \\
+ \\
-\end{array}$ & $\frac{+}{-}$ & $\begin{array}{l}+ \\
+ \\
\end{array}$ & + & $\begin{array}{l}+ \\
+ \\
+\end{array}$ & \pm & $\begin{array}{l}+ \\
+ \\
-\end{array}$ & $\begin{array}{l}t \\
\pm \\
-\end{array}$ & $\begin{array}{l}+ \\
+ \\
- \\
\end{array}$ & $\begin{array}{l}+ \\
+ \\
+\end{array}$ & $\begin{array}{l}+ \\
+ \\
\end{array}$ & $\begin{array}{l}+ \\
+ \\
-\end{array}$ & \pm & \pm \\
\hline 14 & $\begin{array}{l}.1 \\
.05 \\
.025\end{array}$ & $\begin{array}{l}+ \\
+ \\
+\end{array}$ & $\begin{array}{l}+ \\
+ \\
\end{array}$ & $\frac{+}{-}$ & $\begin{array}{l}+ \\
+ \\
\end{array}$ & $\frac{t}{-}$ & $\begin{array}{l}+ \\
+ \\
+ \\
\end{array}$ & $\begin{array}{l}+ \\
+ \\
+\end{array}$ & $\begin{array}{l}+ \\
+ \\
-\end{array}$ & $\begin{array}{l}+ \\
\pm \\
- \\
\end{array}$ & $\begin{array}{l}+ \\
+ \\
+ \\
\end{array}$ & \pm & $\begin{array}{l}+ \\
+ \\
+\end{array}$ & $\begin{array}{l}+ \\
+ \\
- \\
\end{array}$ & $\begin{array}{l}t \\
\pm \\
\end{array}$ & $\begin{array}{l}+ \\
+ \\
\end{array}$ \\
\hline 868 & $\begin{array}{l}.1 \\
.05 \\
.025\end{array}$ & $\begin{array}{l}+ \\
+ \\
-\end{array}$ & $\begin{array}{l}+ \\
+ \\
\end{array}$ & $\underline{+}$ & $\begin{array}{l}+ \\
+ \\
\end{array}$ & $\begin{array}{l}+ \\
+ \\
\end{array}$ & $\begin{array}{l}+ \\
+ \\
-\end{array}$ & $\frac{ \pm}{-}$ & $\begin{array}{l}+ \\
+ \\
-\end{array}$ & $\begin{array}{l}+ \\
+ \\
+\end{array}$ & $\begin{array}{l}+ \\
+ \\
+\end{array}$ & $\frac{t}{-}$ & $\begin{array}{l}+ \\
+ \\
-\end{array}$ & $\begin{array}{l}+ \\
+ \\
-\end{array}$ & $\begin{array}{l}+ \\
+ \\
-\end{array}$ & $\begin{array}{l}+ \\
+\end{array}$ \\
\hline
\end{tabular}

The same 12 hemolytic serums used in testing the hemolytic antigens were used in tests in the same way with 18 nonhemolytic antigens $(18,115,416,425$, $158,4,170,474,73,357,466,132,119,483,211,148,15,420$ ) (table 6). Deducting the number which were not tested with serums 32 and 386,193 tests were made. In these 193 tests, 47 , or $25 \%$, failed to fix complement with $0.1 \mathrm{c} \mathrm{c}$ of serum. With $0.05 \mathrm{cc}$ of serum, 71 , or $36 \%$, of the tests failed to fix complement. Antigens 115 and 175 showed a larger number of failures to fix than any of the other antigens. Both of these antigens fixed in all dilutions with their specific serum.

The five nonhemolytic antiserum were tested with the 18 nonhemolytic antigens (table 7 ). Of the 90 tests represented, 18 , or $20 \%$, failed to fix complement with $0.1 \mathrm{cc}$ of serum. Forty-nine, or $53 \%$, failed to fix complement with $0.05 \mathrm{cc}$ of serum. The failure to fix complement occurred mainly with the same antigens as in the tests with hemolytic serum. The five nonhemolytic 
TABLE 6

COMPIEMENT Fixation

\begin{tabular}{|c|c|c|c|c|c|c|c|c|c|c|c|c|c|c|c|c|c|c|c|}
\hline \multirow{2}{*}{$\begin{array}{c}\text { Antiserum } \\
\text { (hemo- } \\
\text { lytic) }\end{array}$} & \multirow{2}{*}{$\begin{array}{l}\text { Dilu- } \\
\text { tion of } \\
\text { Serum } \\
\text { in c c }\end{array}$} & \multicolumn{18}{|c|}{ Nonhemolytic Antigens } \\
\hline & & 18 & 115 & 416 & 425 & 158 & 4 & 170 & $47 \pm$ & 73 & 457 & 466 & 132 & 119 & 483 & 211 & 148 & 415 & 420 \\
\hline 867 & $\begin{array}{l}.1 \\
.05 \\
.025\end{array}$ & $\begin{array}{l}+ \\
+ \\
+\end{array}$ & $=$ & $\begin{array}{l}+ \\
+ \\
+\end{array}$ & $\begin{array}{l}+ \\
+ \\
+\end{array}$ & $\begin{array}{l}+ \\
+ \\
+\end{array}$ & $\bar{z}$ & $\overline{-}$ & \pm & $\begin{array}{l}+ \\
\pm \\
-\end{array}$ & $\begin{array}{l}+ \\
+ \\
+\end{array}$ & $\bar{z}$ & $\begin{array}{l}+ \\
+ \\
+\end{array}$ & $\begin{array}{l} \pm \\
\pm \\
+\end{array}$ & $\begin{array}{l}+ \\
+ \\
+\end{array}$ & $\begin{array}{l}+ \\
\pm \\
+\end{array}$ & $\begin{array}{l}- \\
-\end{array}$ & $\begin{array}{l}+ \\
\pm \\
-\end{array}$ & \pm \\
\hline 872 & $\begin{array}{l}.1 \\
.05 \\
.025\end{array}$ & \pm & $\bar{z}$ & $\begin{array}{l}+ \\
+ \\
+\end{array}$ & $\begin{array}{l}+ \\
+ \\
+\end{array}$ & $\begin{array}{l}+ \\
+ \\
+\end{array}$ & z & $=$ & \pm & $\begin{array}{l}+ \\
+ \\
+\end{array}$ & $\begin{array}{l}+ \\
+ \\
+\end{array}$ & $\begin{array}{l}+ \\
+ \\
-\end{array}$ & $\begin{array}{l}+ \\
+ \\
+\end{array}$ & $\begin{array}{l}+ \\
+ \\
+\end{array}$ & $\begin{array}{l}+ \\
+ \\
+\end{array}$ & $\begin{array}{l}+ \\
+ \\
+\end{array}$ & $\begin{array}{l}+ \\
\pm \\
-\end{array}$ & $\begin{array}{l}+ \\
+ \\
+\end{array}$ & \pm \\
\hline 368 & $\begin{array}{l}.1 \\
0.5 \\
.025\end{array}$ & $\begin{array}{l}+ \\
+\end{array}$ & $=$ & $\begin{array}{l}+ \\
\pm \\
-\end{array}$ & $\begin{array}{l} \pm \\
+ \\
-\end{array}$ & $\bar{z}$ & \pm & $=$ & $\begin{array}{l} \pm \\
\pm \\
\pm\end{array}$ & $\begin{array}{l}+ \\
+ \\
-\end{array}$ & $\begin{array}{l}+ \\
+ \\
+\end{array}$ & $=$ & $\begin{array}{l}+ \\
+ \\
-\end{array}$ & $\begin{array}{l}+ \\
\pm \\
-\end{array}$ & \pm & \pm & $\begin{array}{l} \pm \\
\pm \\
-\end{array}$ & $\begin{array}{l}+ \\
+ \\
-\end{array}$ & \pm \\
\hline 399 & $\begin{array}{l}.1 \\
.05 \\
.025\end{array}$ & $\begin{array}{l}+ \\
+ \\
+\end{array}$ & $\bar{z}$ & $\begin{array}{l}+ \\
+ \\
+\end{array}$ & $\begin{array}{l}+ \\
+ \\
+\end{array}$ & $\begin{array}{l}+ \\
\pm \\
-\end{array}$ & \pm & $=$ & $\begin{array}{l} \pm \\
\pm \\
-\end{array}$ & $\begin{array}{l}+ \\
+ \\
+\end{array}$ & $\begin{array}{l}+ \\
+ \\
+\end{array}$ & $\begin{array}{l}+ \\
+ \\
+\end{array}$ & $\begin{array}{l}+ \\
+ \\
+\end{array}$ & $\begin{array}{l}+ \\
+ \\
-\end{array}$ & $\begin{array}{l}+ \\
+ \\
+\end{array}$ & $\begin{array}{l}+ \\
\pm \\
+\end{array}$ & $=$ & $\begin{array}{l}+ \\
+ \\
-\end{array}$ & $\bar{z}$ \\
\hline 2 & $\begin{array}{l}.1 \\
.05 \\
.025\end{array}$ & $\begin{array}{l}+ \\
+ \\
+\end{array}$ & $\bar{z}$ & \pm & $\begin{array}{l}+ \\
+ \\
+\end{array}$ & $\bar{z}$ & \pm & $\bar{z}$ & \pm & \pm & $\begin{array}{l}+ \\
+ \\
-\end{array}$ & $\bar{z}$ & \pm & $\begin{array}{l}+ \\
+ \\
\pm\end{array}$ & $\begin{array}{l}+ \\
\pm\end{array}$ & $\begin{array}{l}+ \\
\pm \\
-\end{array}$ & \pm & $\begin{array}{l}+ \\
\pm \\
+\end{array}$ & \pm \\
\hline 32 & $\begin{array}{l}.1 \\
.05 \\
.025\end{array}$ & $=$ & $\bar{z}$ & \pm & $\bar{z}$ & $\bar{z}$ & $\bar{Z}$ & & & & & & & & & & & & \\
\hline 411 & $\begin{array}{l}.1 \\
.05 \\
.025\end{array}$ & $\begin{array}{l}+ \\
+ \\
+\end{array}$ & $\begin{array}{l}+ \\
+ \\
+\end{array}$ & $\begin{array}{l}+ \\
+ \\
+\end{array}$ & $\begin{array}{l}+ \\
+ \\
+\end{array}$ & $=$ & \pm & $=$ & \pm & \pm & $\begin{array}{l}+ \\
+ \\
-\end{array}$ & \pm & $\frac{ \pm}{-}$ & $\begin{array}{l}+ \\
+ \\
-\end{array}$ & \pm & $\begin{array}{l}+ \\
+ \\
+\end{array}$ & $\frac{+}{-}$ & $\begin{array}{l}+ \\
\pm \\
-\end{array}$ & $\begin{array}{l} \pm \\
-\end{array}$ \\
\hline 371 & $\begin{array}{l}.1 \\
.05 \\
.025\end{array}$ & $\begin{array}{l}+ \\
+ \\
+\end{array}$ & $\bar{z}$ & \pm & $\begin{array}{l}+ \\
+ \\
+\end{array}$ & $\bar{Z}$ & $\bar{E}$ & $=$ & $\begin{array}{l}+ \\
+ \\
+\end{array}$ & + & $\begin{array}{l}+ \\
+ \\
+\end{array}$ & $\bar{z}$ & $\begin{array}{l}+ \\
+ \\
-\end{array}$ & $\begin{array}{l}+ \\
+ \\
+\end{array}$ & $\begin{array}{l}+ \\
+ \\
-\end{array}$ & $=$ & $\overline{-}$ & \pm & \pm \\
\hline 345 & $\begin{array}{l}.1 \\
.05 \\
.025\end{array}$ & $\begin{array}{l}+ \\
+ \\
+\end{array}$ & $\begin{array}{l} \pm \\
+ \\
-\end{array}$ & \pm & $\begin{array}{l}+ \\
+ \\
+\end{array}$ & $\begin{array}{l}+ \\
\pm \\
-\end{array}$ & $\stackrel{+}{+}$ & $\bar{z}$ & \pm & $\begin{array}{l}+ \\
+ \\
+\end{array}$ & $\begin{array}{l}+ \\
+ \\
+\end{array}$ & \pm & $\begin{array}{l}+ \\
+ \\
+\end{array}$ & $\begin{array}{l}+ \\
+ \\
+\end{array}$ & $\begin{array}{l}+ \\
\pm \\
-\end{array}$ & $\begin{array}{l}+ \\
+ \\
+\end{array}$ & \pm & $\begin{array}{l}+ \\
\pm \\
-\end{array}$ & $\stackrel{+}{+}$ \\
\hline 174 & $\begin{array}{l}.1 \\
.05 \\
.025\end{array}$ & $\begin{array}{l}+ \\
+ \\
+\end{array}$ & $\frac{ \pm}{-}$ & $\begin{array}{l} \pm \\
\pm\end{array}$ & $\begin{array}{l}+ \\
\pm \\
-\end{array}$ & $\bar{z}$ & $\overline{-}$ & $\frac{ \pm}{-}$ & $\begin{array}{l}+ \\
+ \\
+\end{array}$ & \pm & $\begin{array}{l}+ \\
\pm \\
-\end{array}$ & \pm & \pm & $\begin{array}{l}+ \\
+ \\
+\end{array}$ & $\begin{array}{l}+ \\
+ \\
+\end{array}$ & $\vec{z}$ & \pm & \pm & $\begin{array}{l}+ \\
\pm \\
+\end{array}$ \\
\hline 386 & $\begin{array}{l}.1 \\
.05 \\
.025\end{array}$ & \pm & \pm & \pm & $\begin{array}{l} \pm \\
\pm \\
-\end{array}$ & $\begin{array}{l}\bar{z} \\
-\end{array}$ & $=$ & $\bar{z}$ & & & & & & & & & & & \\
\hline 14 & $\begin{array}{l}.1 \\
0.5 \\
.025\end{array}$ & & \pm & \pm & $\begin{array}{l}+ \\
+ \\
+\end{array}$ & $\bar{z}$ & $\overline{-}$ & $\bar{z}$ & \pm & $\stackrel{+}{+}$ & $\begin{array}{l}+ \\
+ \\
+\end{array}$ & $\begin{array}{l}+ \\
\pm \\
-\end{array}$ & $\frac{ \pm}{-}$ & $\begin{array}{l}+ \\
+ \\
+\end{array}$ & $\begin{array}{l}+ \\
+ \\
-\end{array}$ & \pm & \pm & $\begin{array}{l}+ \\
\pm\end{array}$ & \pm \\
\hline
\end{tabular}

serums were further tested with the 15 hemolytic antigens (table 8). This represents 75 tests, of which 7 , or $9 \%$, failed to fix complement with $0.1 \mathrm{cc}$ of serum, and 35 , or $47 \%$, failed to fix with $0.05 \mathrm{cc}$ of serum. The percentages of failure to fix complement may be summarized as follows:

Hemolytic serum $(0.1 \mathrm{cc})$ plus hemolytic antigen.... $2 \%$ failure Hemolytic serum $(0.05 \mathrm{cc})$ plus hemolytic antigen.... 16\% failure Nonhemolytic serum $(0.1$ c c) plus nonhemolytic

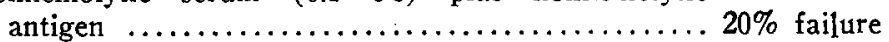

Nonhemolytic serum $(0.05$ cc) plus nonhemolytic

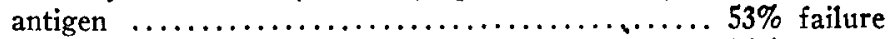

Hemolytic serum $(0.1 \mathrm{cc})$ plus nonhemolytic antigen. $25 \%$ failure Hemolytic serum $(0.05 \mathrm{cc})$ plus nonhemolytic antigen $36 \%$ failure Nonhemolytic serum $(0.1 \mathrm{cc})$ plus hemolytic antigen. $9 \%$ failure Nonhemolytic serum $(0.05 \mathrm{cc})$ plus hemolytic antigen $47 \%$ failure 
As shown by these tests, it seems that there is a greater constancy among hemolyzers than there is between hemolyzers and nonhemolyzers or among nonhemolyzers themseives.

In general, the results obtained in agglutination and complement fixation seem to. agree with the findings of Kinsella and Swift, who, by fixation tests, decided that the hemolytic organisms represented a homogeneous group, and the nonhemolytic organisms represented a heterogeneous group, having a lefthanded element more closely related to the hemolytic group than the righthanded element. A relationship between a grouping based on agglutination or complement fixation and a grouping based on fermentation reactions or source does not seem to be evident.

TABLE 7

COMPlement Fixation

\begin{tabular}{|c|c|c|c|c|c|c|c|c|c|c|c|c|c|c|c|c|c|c|c|}
\hline \multirow{2}{*}{$\begin{array}{l}\text { Antigerum } \\
\text { (nonhemo- } \\
\text { lytic) }\end{array}$} & \multirow{2}{*}{$\begin{array}{l}\text { Dilu- } \\
\text { tjon of } \\
\text { Serum } \\
\text { in e e }\end{array}$} & \multicolumn{18}{|c|}{ Nonhemolytic Antigens } \\
\hline & & 18 & 115 & 416 & 425 & 158 & 4 & 170 & 474 & 73 & 457 & 466 & 132 & 119 & 483 & 211 & 148 & 415 & 420 \\
\hline 416 & $\begin{array}{l}.1 \\
.05 \\
.025\end{array}$ & $\begin{array}{l}+ \\
+ \\
+\end{array}$ & $\begin{array}{l}+ \\
+ \\
+\end{array}$ & $\begin{array}{l}+ \\
+ \\
+\end{array}$ & $\begin{array}{l}+ \\
+ \\
+\end{array}$ & $=$ & \pm & $\begin{array}{l}\overline{-} \\
-\end{array}$ & $\begin{array}{l} \pm \\
-\end{array}$ & \pm & $\begin{array}{l}+ \\
+ \\
-\end{array}$ & $\frac{ \pm}{-}$ & \pm & \pm & \pm & $\begin{array}{l}+ \\
+ \\
+\end{array}$ & \pm & $\begin{array}{l}+ \\
+ \\
-\end{array}$ & \pm \\
\hline 158 & $\begin{array}{l}.1 \\
.05 \\
.025\end{array}$ & $\begin{array}{l}+ \\
+ \\
+\end{array}$ & $\bar{z}$ & $\begin{array}{l}+ \\
\pm \\
-\end{array}$ & \pm & $\begin{array}{l}+ \\
+ \\
+\end{array}$ & $\begin{array}{l} \pm \\
\pm \\
-\end{array}$ & $=$ & $=$ & $\begin{array}{l}+ \\
+ \\
+\end{array}$ & $\begin{array}{l}+ \\
\pm \\
-\end{array}$ & $\begin{array}{l}+ \\
\pm \\
-\end{array}$ & $\begin{array}{l}+ \\
+ \\
+\end{array}$ & $\frac{ \pm}{-}$ & \pm & \pm & $=$ & 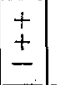 & \pm \\
\hline 425 & $\begin{array}{l}.1 \\
.05 \\
.025\end{array}$ & $\begin{array}{l}+ \\
+ \\
+\end{array}$ & \pm & $\begin{array}{l}+ \\
+ \\
+\end{array}$ & $\begin{array}{l}+ \\
+ \\
+\end{array}$ & $=$ & $=$ & $=$ & $\begin{array}{l} \pm \\
\pm \\
\pm\end{array}$ & $=$ & $\begin{array}{l}+ \\
+ \\
+\end{array}$ & $\begin{array}{l}+ \\
\pm \\
-\end{array}$ & $\begin{array}{l}+ \\
+ \\
-\end{array}$ & \pm & $\begin{array}{l}+ \\
+ \\
+\end{array}$ & $\begin{array}{l}+ \\
+ \\
+\end{array}$ & $\begin{array}{l}+ \\
+ \\
+\end{array}$ & $\begin{array}{l}+ \\
+\end{array}$ & $\frac{ \pm}{-}$ \\
\hline 4 & $\begin{array}{l}.1 \\
.05 \\
.025\end{array}$ & \pm & $\begin{array}{l}+ \\
+ \\
-\end{array}$ & $\begin{array}{l} \pm \\
\pm \\
-\end{array}$ & \pm & $\frac{ \pm}{-}$ & $\begin{array}{l}+ \\
+ \\
+\end{array}$ & $\frac{+}{-}$ & $\begin{array}{l}- \\
-\end{array}$ & $\begin{array}{l}+ \\
+ \\
+\end{array}$ & $\frac{ \pm}{-}$ & $=$ & \pm & $\frac{ \pm}{-}$ & \pm & $=$ & \pm & $\frac{ \pm}{-}$ & $\frac{ \pm}{-}$ \\
\hline 115 & $\begin{array}{l}.1 \\
.05 \\
.025\end{array}$ & $\stackrel{+}{+}$ & $\begin{array}{l}+ \\
+ \\
+\end{array}$ & $\begin{array}{l}+ \\
+ \\
+\end{array}$ & $\begin{array}{l}+ \\
+ \\
+\end{array}$ & \pm & $=$ & $\overline{-}$ & $\begin{array}{l}+ \\
\pm \\
-\end{array}$ & $\begin{array}{l} \pm \\
\pm \\
-\end{array}$ & $\begin{array}{l}+ \\
+ \\
+\end{array}$ & $\begin{array}{l}+ \\
\pm \\
-1\end{array}$ & $\mid \begin{array}{l} \pm \\
-\end{array}$ & $\begin{array}{l}+ \\
+ \\
+\end{array}$ & \pm & \pm & \pm & $\stackrel{+}{ \pm}$ & $\frac{t}{-}$ \\
\hline
\end{tabular}

TABLE 8

Compleanent Fixation

\begin{tabular}{|c|c|c|c|c|c|c|c|c|c|c|c|c|c|c|c|c|}
\hline \multirow{2}{*}{$\begin{array}{c}\text { Antiserum } \\
\text { (nonhemolytic) }\end{array}$} & \multirow{2}{*}{$\begin{array}{l}\text { Dilution } \\
\text { of Serum } \\
\text { in e c }\end{array}$} & \multicolumn{15}{|c|}{ Hemolytic Antigens } \\
\hline & & 367 & 38 & 32 & 30 & 2 & 174 & 345 & 411 & 386 & 371 & 152 & 14 & 177 & 166 & 159 \\
\hline 426 & $\begin{array}{l}.1 \\
.05 \\
.025\end{array}$ & \pm & \pm & + & $\begin{array}{l}+ \\
+\end{array}$ & \pm & $\begin{array}{l}+ \\
\pm \\
-\end{array}$ & $\begin{array}{l} \pm \\
\pm \\
\end{array}$ & \pm & \pm & \pm & \pm & + & $\begin{array}{c}+ \\
+ \\
+\end{array}$ & $\begin{array}{l}+ \\
+\end{array}$ & $\begin{array}{l}+ \\
+ \\
+\end{array}$ \\
\hline 158 & $\begin{array}{l}.1 \\
.05 \\
.025\end{array}$ & \pm & \pm & $=$ & \pm & \pm & \pm & $=$ & $\begin{array}{l}+ \\
+ \\
+\end{array}$ & \pm & $\begin{array}{l}+ \\
+ \\
+\end{array}$ & \pm & \pm & $=$ & $\begin{array}{l}+ \\
+ \\
+\end{array}$ & $\begin{array}{l}+ \\
+\end{array}$ \\
\hline 425 & $\begin{array}{l}.1 \\
.05 \\
.025\end{array}$ & + & $\begin{array}{l}+ \\
+\end{array}$ & $\begin{array}{l}+ \\
+ \\
+\end{array}$ & $\begin{array}{l}+ \\
+ \\
+\end{array}$ & \pm & $\begin{array}{l}+ \\
+ \\
+\end{array}$ & \pm & \pm & $\frac{ \pm}{-}$ & $\begin{array}{l}t \\
+ \\
+\end{array}$ & $\begin{array}{l}+ \\
+ \\
-\end{array}$ & $\begin{array}{l}+ \\
+ \\
+\end{array}$ & $\begin{array}{l}+ \\
\pm\end{array}$ & $\begin{array}{l}+ \\
+ \\
+\end{array}$ & + \\
\hline 4 & $\begin{array}{l}.1 \\
.05 \\
.025\end{array}$ & $=$ & $\frac{ \pm}{-}$ & $\bar{z}$ & $\frac{+}{-}$ & $\frac{1}{-}$ & \pm & $\bar{z}$ & \pm & \pm & $\begin{array}{l}+ \\
\pm \\
+\end{array}$ & \pm & \pm & $=$ & $\begin{array}{l}+ \\
+ \\
\end{array}$ & $\begin{array}{l}+ \\
\pm \\
\end{array}$ \\
\hline 115 & $\begin{array}{l}.1 \\
.05 \\
.025\end{array}$ & \pm & \pm & $\stackrel{+}{+}$ & $\begin{array}{l}+ \\
+\end{array}$ & $\begin{array}{l}+ \\
+ \\
+\end{array}$ & $\begin{array}{l}+ \\
+ \\
+\end{array}$ & $\begin{array}{l}+ \\
+ \\
+\end{array}$ & $\frac{ \pm}{-}$ & \pm & $\begin{array}{l}+ \\
+ \\
+\end{array}$ & \pm & $\begin{array}{l}+ \\
+ \\
-\end{array}$ & $\begin{array}{l}+ \\
+\end{array}$ & $\stackrel{+}{+}$ & $\begin{array}{l}+ \\
+ \\
+\end{array}$ \\
\hline
\end{tabular}


SUMMARY AND CONCLUSIONS

There seems to be no direct relationship between the length of chains and pathogenesis in streptococci.

Pleomorphic strains may change to segmented chains with slightly elongated cells.

Capsules are less commonly found among hemolyzers than among nonhemolyzers.

Hemolysis as shown in this series of 134 strains is constant even after nearly two years of artificial cultivation.

Evidence points to the fact that all nonhemolytic strains are methemoglobin producers when grown on suitable mediums.

Thirty-seven per cent. of 200 normal throats examined contained hemolytic streptococci. Hemolytic streptococci may be present in horse feces, crypts of tonsils, milk, throats of dogs, and occasionally in human feces.

Of. the 134 hemolytic strains, only four regularly failed to ferment lactose. Lactose was fermented by these four strains at a longer period of incubation than five days. Only two of the hemolytic strains always fermented mannite; and only three always failed to ferment salicin.

There seems to be more uniformity of fermentation among the hemolytic streptococci than among the nonhemolytic.

None of the minor groups of hemolytic streptococci show sufficient relation to source, habits or pathogenesis to warrant a separate classification.

The term Str. hemolyticus is to be preferred to Str. pyogenes.

Of the 150 strains of nonhemolyzers, only five always failed to ferment lactose; 36 always fermented mannite, and 75 always fermented salicin.

The regular type of fermentation places most of the nonhemolyzers in the class Str. mitis and salivarius according to Holman, or Str. buccalis according to Blake.

Considering the lack of relationship between fermentation reactions and source or pathogenesis, and the wide distribution of organisms falling into nonhemolytic groups, it is doubtful whether any of the smaller groups of the nonhemolytic streptococci deserve a place in classification.

The term Str. viridans seems to be preferable to Str. buccalis. 
Agglutination reactions between hemolytic organisms and homologous serum in the series examined show a high degree of uniformity. The reactions of hemolytic serum with nonhemolytic organisms, nonhemolytic serum with hemolytic organisms, or nonhemolytic serum with nonhemolytic organisms, except with homologous strains, give a low percentage of positive results.

The reactions of hemolytic serum with hemolytic antigen yield a higher percentage of complement fixation than those of hemolytic serum with nonhemolytic antigen, nonhemolytic serum with nonhemolytic antigen, or nonhemolytic serum with hemolytic antigen.

The results of both agglutination and complement fixation tests strengthen the belief that the hemolytic group is a homogeneous group in which there is a relatively high degree of constancy and that the nonhemolytic group is heterogeneous or at all events less homogeneous than the hemolytic group. 